Review

\title{
Everything You Always Wanted to Know about $\beta_{3}-A R *(*$ But Were Afraid to Ask)
}

\author{
Giorgia Schena * (D) and Michael J. Caplan \\ Department of Cellular and Molecular Physiology, Yale University School of Medicine, \\ New Haven, CT 06510, USA; michael.caplan@yale.edu \\ * Correspondence: giorgia.schena@yale.edu; Tel.: +1-203-785-6833
}

Received: 19 February 2019; Accepted: 12 April 2019; Published: 16 April 2019

\begin{abstract}
The beta-3 adrenergic receptor $\left(\beta_{3}-\mathrm{AR}\right)$ is by far the least studied isotype of the beta-adrenergic sub-family. Despite its study being long hampered by the lack of suitable animal and cellular models and inter-species differences, a substantial body of literature on the subject has built up in the last three decades and the physiology of $\beta_{3}$-AR is unraveling quickly. As will become evident in this work, $\beta_{3}$-AR is emerging as an appealing target for novel pharmacological approaches in several clinical areas involving metabolic, cardiovascular, urinary, and ocular disease. In this review, we will discuss the most recent advances regarding $\beta_{3}$-AR signaling and function and summarize how these findings translate, or may do so, into current clinical practice highlighting $\beta_{3}-A R^{\prime} s$ great potential as a novel therapeutic target in a wide range of human conditions.
\end{abstract}

Keywords: beta-3 adrenergic receptor; therapeutic target; G-protein coupled receptors

\section{Introduction}

Soon after the subdivision of $\beta$-adrenoceptors into subtypes $\beta_{1}$ and $\beta_{2}$, it became clear that the pharmacological profile of some apparently $\beta$-adrenoceptor-mediated responses did not fit either of these two subtypes [1]. However, the existence of a third subtype, $\beta_{3}-\mathrm{AR}$, was not universally accepted until it was first cloned in 1989 [2]. Ever since then, $\beta_{3}$-AR expression has been reported in several tissues revealing, completely or in part, new details on its signaling pathways and on the variety of functions that it mediates. New aspects of $\beta_{3}$-AR have recently been described, involving it in urine concentrating mechanisms [3], fat mass reduction [4], and inflammatory processes [5,6] thus opening the way for new potential therapeutic applications. Importantly, $\beta_{3}$-AR agonist mirabegron is the first of this class of compounds that has been approved for the treatment of overactive bladder syndrome and one of the few alternatives to anticholinergic medications [7]. Given $\beta_{3}$-AR expression and signaling in districts such as myocardium and adipose tissue, mirabegron is also being tested in repurposing trials for cardiovascular and metabolic conditions (commented on in $[8,9])$. Consistently, $\beta_{3}$-AR's most common genetic variant, Trp64Arg, has been found to positively correlate with metabolic parameters such as HDL-C (High Density Lipoprotein-Cholesterol) and LDL-C (Low Density Lipoprotein-Cholesterol) accumulation rates and glucose tolerance $[10,11]$. After a brief overview of basic information regarding gene structure, protein, and pharmacology of the receptor, we will focus on $\beta_{3}$-AR role in some of the main tissues where its expression has been reported. In each subsection, we will review the state of the art in signaling pathways and potential therapeutic approaches with a focus on studies in humans and rodents.

\section{Gene and Protein}

The gene encoding $\beta_{3}$-AR has been identified in several species such as rat [12], mouse [13], bovine, sheep, goat [14], and dog [15]. In humans, the gene is localized on chromosome 8 and shares a 
$51 \%$ and $46 \%$ identity with $\beta_{1}$ - and $\beta_{2}$-AR amino-acid sequences, respectively. This is mostly limited to the transmembrane domains and membrane-proximal regions of the intracellular loops, parts of the receptor respectively involved in ligand binding and G-protein interactions $[16,17]$. The mouse and human $\beta_{3}$-AR are $81 \%$ identical, with the highest homology in the transmembrane domains $(94 \%)$, and the lowest in the C-terminal tail and third intracellular loop. Consistently, their C-terminal regions differ in sequence and length, ranging from 6 (human) to 12 (mouse and rat) additional residues. $\beta_{3}$-AR gene also contains introns. The number of exons/introns of the human and rodent genes differs and can be summarized as follows: the human $\beta_{3}$-AR gene is composed of two exons and a single intron while in mouse, there are three exons and two introns [18]. In both species, exon 1 spans the $5^{\prime}$ untranslated region and the major part of the coding block; however, in humans, exon 2 only contains $19 \mathrm{bp}$ of the coding region (last 6 aa of the C-terminus) and the $3^{\prime}$ untranslated region; in mouse it contains 37 coding nucleotides and $31 \mathrm{bp}$ of $3^{\prime}$ untranslated region, the remainder of which is carried by exon 3 [19]. Despite intron presence, no spliced variants have been described for the human $\beta_{3}$-AR gene, whereas two have been characterized in the mouse [19-21].

$\beta_{3}$-AR gene encodes a single 408-amino acid residue-long peptide chain that, together with $\beta_{1}$ - and $\beta_{2}$-AR, belongs to the G-protein coupled receptor (GPCR) family characterized by seven transmembrane (TM) domains, with three intracellular and three extracellular loops. The N-terminal region of $\beta_{3}$-AR is extracellular and glycosylated, whereas the C-terminus is intracellular. Unlike in $\beta_{1}$ and $\beta_{2}-A R$, it lacks sites for phosphorylation by protein kinase $A$ (PKA) and $\beta$-adrenoceptor kinase ( $\beta$ ARK) thereby making $\beta_{3}$-AR relatively resistant to desensitization $[17,22,23]$. Among others, this feature contributed in making $\beta_{3}$-AR an interesting therapeutic target that would potentially be suitable for chronic treatments. From a molecular point of view, desensitization of $\beta_{3}$-AR might not be mediated by internalization/degradation of the receptor, as for $\beta_{1}$-AR [24], but rather by downregulation of downstream components of the signaling pathway [25] or even mRNA regulation (reviewed in [23]). However, caution must be used when evaluating the data present in literature as results were not always consistent (reviewed in [23]). Transmembrane domains TM3, TM4, TM5, and TM6 are essential for ligand binding, whereas TM2 and TM7 are involved in G $\alpha$ s activation [26]. The disulphide bond between extracellular loops 2 and 3 is also essential for ligand binding and activity of the receptor. The Cys361 residue in the fourth intracellular loop is palmitoylated. Palmitoylation has been shown to mediate adenylyl cyclase stimulation by the agonist bound receptor, possibly by promoting the insertion of several adjacent residues into the membrane and thus forming an additional intracellular loop, resulting in an active conformation for G-protein coupling [27].

\section{Pharmacology of the Receptor}

The criteria that are used to define a characteristic $\beta_{3}$-AR pharmacological response have been defined in several studies [26,28-32] and can be summarized as follows. $\beta_{3}$-AR has high affinity and potency for selective agonists such as mirabegron, vibegron, solabegron, and ritobegron; partial agonist activity of $\beta_{1}$ - and $\beta_{2}$-AR antagonists, such as CGP12177A, bucindolol, and pindolol; an atypically low affinity for $\beta$-AR antagonists such as propranolol and nadolol; and lastly, poor stereoselectivity for reference agonist and antagonist enantiomers in respect to the values reported for traditional $\beta_{1}$ - and $\beta_{2}$-AR. Several studies that clarify $\beta_{3}$-AR pharmacology were published in the last 20 years and are summarized in a comprehensive review by Donny Strosberg [33]. Structurally, most of the ligands share a similar backbone, with three domains: a left- and right-hand side connected by a linker. The left-hand side is typically an arylethanolamine or aryloxypropanolamine [34], the linker has various structures including both aromatic and aliphatic moieties, the right-hand side typically contains polar and/or ionizable functionalities [35]. A great number of ligands have been tested so far, but their assignment to either one or the other category remains controversial $[36,37]$. 


\subsection{Agonists}

$\beta_{3}$-AR agonists fall in two classes depending on the time of their discovery [35]: the first-generation compounds such as BRL37344 and CL316243, were developed in the 1990s while the second-generation followed or were improved later (see Table 1 for a list of agonists tested in clinical trials).

Table 1. $\beta_{3}$-AR agonists tested in clinical trials.

\begin{tabular}{|c|c|c|c|c|}
\hline Compound & Manufacturer/Sponsor & $\begin{array}{l}\text { Therapeutic } \\
\text { Indications }\end{array}$ & Status & References \\
\hline $\begin{array}{l}\text { Mirabegron } \\
\text { (YM178) }\end{array}$ & Astellas Pharma & $\begin{array}{l}\text { Overactive bladder } \\
\text { syndrome }\end{array}$ & FDA-approved & [38] \\
\hline $\begin{array}{l}\text { Amibegron } \\
\text { (SR58611A) }\end{array}$ & Sanofi & $\begin{array}{l}\text { Antidepressant, } \\
\text { antianxiolytic }\end{array}$ & $\begin{array}{l}\text { Phase II and III } \\
\text { (2005-2008) then } \\
\text { discontinued }^{1}\end{array}$ & $\begin{array}{c}\text { [39-41]; } \\
\text { Clinicaltrials.gov } \\
\text { NCT00252330 }\end{array}$ \\
\hline $\begin{array}{l}\text { Solabegron } \\
\text { (GW427353) }\end{array}$ & Glaxosmithkline & $\begin{array}{l}\text { Overactive bladder } \\
\text { syndrome }\end{array}$ & Phase II (ongoing) & $\begin{array}{c}{[42,43] ;} \\
\text { Clinicaltrials.gov } \\
\text { NCT03475706 }\end{array}$ \\
\hline $\begin{array}{l}\text { Ritobegron } \\
\text { (KUC-7483) }\end{array}$ & $\begin{array}{l}\text { Kissei Pharmaceuticals Co. } \\
\text { Ltd. }\end{array}$ & $\begin{array}{l}\text { Overactive bladder } \\
\text { syndrome }\end{array}$ & $\begin{array}{c}\text { Phase III } \\
\text { Discontinued }{ }^{1}\end{array}$ & $\begin{array}{c}\text { [42-45]; } \\
\text { Clinicaltrials.gov } \\
\text { NCT01003405 }\end{array}$ \\
\hline Vibegron $^{2}$ & $\begin{array}{c}\text { Kyorin Pharmaceutical Co., } \\
\text { Ltd. and Kissei } \\
\text { Pharmaceutical Co., Ltd. }\end{array}$ & $\begin{array}{l}\text { Overactive bladder } \\
\text { syndrome }\end{array}$ & $\begin{array}{c}\text { Approved } \\
\text { (Japan) }\end{array}$ & {$[46,47]$} \\
\hline
\end{tabular}

BRL37344 is possibly the most widely used of all of the $\beta_{3}$-AR agonists in both human and mouse settings, but its pharmacology is controversial. It displays a higher affinity for rodent $\beta_{3}$-AR vs. human $\beta_{3}$-AR and also higher potency measured as the ability in stimulating adenylyl cyclase $[13,48]$. Nonetheless, BRL37344 was recently used to corroborate the hypothesis that $\beta_{3}$-ARs are involved in the relaxation of human detrusor muscle and of human corpus cavernosum $[49,50]$. More than one study has reported high potency ( $\mathrm{pEC} 50=6.5-7.5)$ similar to that of the non-selective agonist isoproterenol and to the selective agonist mirabegron on human bladder strips [49,51]. Finally, while some studies report that BRL37344 has a higher selectivity for $\beta_{3}$-AR vs. $\beta_{1}$ - and $\beta_{2}$-AR [31] some others point out that it is able to activate other $\beta$-ARs [52,53]. CL316243 exhibits a low potency but a good selectivity for the human $\beta_{3}$-AR: $>128$ - and 10-fold higher than $\beta_{1}$ - and $\beta_{2}$-AR, respectively [28]. It has been used in studies on the relaxation of pre-contracted human detrusor [54]. CL316243 appears to be more selective against the rodent $\beta_{3}-\mathrm{AR}$, as its potency to stimulate cAMP formation in transfected $\mathrm{CHO}$ cells was found to be higher with mouse vs. human $\beta_{3}$-AR (pEC50 8.7 vs. 4.3) [55]. CL316243 was recently found to elicit significant anabolic effects in mouse skeletal muscle [56] although the authors do not address the possibility of a simultaneous activation of $\beta_{2}$-AR, the predominant isotype in skeletal muscle [57]. It was also used in a study addressing potential therapies for the vascular complication of diabetes, where it reduced the levels of reactive oxygen species and improved endothelium-dependent relaxation [58].

Second-generation agonists include FDA-approved molecules like mirabegron (YM178), yet discontinued ones such as amibegron (SR58611A) and other molecules that are currently being validated in phase II and III clinical trials, such as solabegron (GW427353) and ritobegron (KUC-7483). Mirabegron, solabegron, and KUC-7322 (the active metabolite of ritobegron) have been tested for their abilities to induce human detrusor relaxation. Mirabegron and solabegron were proven to be highly selective in stimulating cAMP accumulation in CHO cells transfected with human $\beta_{3}-\mathrm{AR}$ $(\mathrm{EC} 50 \approx 22 \mathrm{nM}$ ), with intrinsic activities comparable to reference agonist isoproterenol. When tested on pre-contracted human bladder strips, mirabegron produced a concentration-dependent relaxation with an EC50 of $0.78 \mu \mathrm{M}$, similar to isoproterenol $(\mathrm{EC} 50=0.28 \mu \mathrm{M})$ [38] while ritobegron had an EC50 of $1.1 \mu \mathrm{M}$ [44]. Solabegron has been found to relax isolated human bladder strips at low 
concentrations and this effect was partially counteracted by pre-incubation with selective antagonist SR59230A [59]. It also reduced detrusor spontaneous contractile activity by almost $80 \%$. Amibegron was first described for its inhibitory effect on rat colon motility [39]. Subsequently, Simiand et al. showed its antidepressant properties in predictive mechanistic models [41], but these studies were halted due to the lack of proof of $\beta_{3}$-AR expression in the central nervous system. Finally, when $\beta_{3}$-AR presence was reported in humans and rodents $[60,61]$, several studies described the potential use of amibegron as an antidepressant and antianxiolytic drug in rodents, reporting good efficacy, selectivity for $\beta_{3}-A R$, and overall lack of side effects [62-65].

With $\beta_{3}$-AR gaining more and more importance as a therapeutic target, the screening for new compounds is progressing at a fast pace [66,67]. Of note, an innovative approach integrating energetic analysis, structure-based pharmacophores, and virtual screening was successfully used to screen 233,450 compounds for active $\beta_{3}$-AR agonists and to identify common structural characteristics in the active molecules [68].

\subsection{Antagonists}

A key reason that $\beta_{3}$-AR was identified later than $\beta_{1}$ - and $\beta_{2}$-AR is its much lower affinity for classical $\beta$-AR antagonists. For instance, propranolol and bupranolol showed 140- and 17-fold higher affinity for $\beta_{1}$ - and $\beta_{2}$-AR and $>500$ - and 30-fold higher affinity for $\beta_{1}$ - and $\beta_{2}$-AR, respectively $[28,31]$. Two of the most widely used $\beta_{3}$-AR antagonists are SR59230A and L748337. SR59230A belongs to the class of aryloxypropanolaminotetralins [69] and was first listed as a putative $\beta_{3}$-AR antagonist in rat gut while also displaying interesting properties in rat Brown Adipose Tissue (BAT) blunting $\beta_{3}$-AR-mediated cAMP increase [70]. Despite its wide use in antagonizing $\beta_{3}$-AR-mediated responses [71-73], SR59230A has been reported to be essentially non-selective and if anything to have a lower affinity for human $\beta_{3}$-AR vs. $\beta_{1}$ - and $\beta_{2}$-AR $[31,37,51,74]$. It also displayed a partial agonistic activity, promoting cAMP accumulation in $\mathrm{CHO}$ cells transfected with the mouse $\beta_{3}$-AR receptor [75] as well as increases in the extracellular acidification rate (ECAR) [76]. Lastly, this compound also behaves as a strong biased agonist for other signaling pathways involving $\beta_{3}$-AR [76]. These findings limit the use of SR59230A as an antagonist to identify $\beta_{3}$-AR responses, at least when not assessed in combination with other compounds.

Pre-incubation with L748337 blunted cAMP accumulation in CHO cells expressing human $\beta_{3}$-AR and also reduced glycerol production in rhesus monkey adipose tissue. It was reported to have a 100 -fold higher affinity $(\mathrm{Ki}=4 \mathrm{nM})$ for the human $\beta_{3}$-AR vs. $\beta_{1}$ - and $\beta_{2}$-AR, and also vs. The rat $\beta_{3}$-AR [77]. Accordingly, a tritiated version of L748337 with a 10-times higher affinity for the human receptor against the rodent was proposed as a $\beta_{3}$-selective radioligand [78]. As seen for SR59230A, it was reported to have a significant agonistic activity in promoting phosphorylation of extracellular signal regulated kinase 1/2 (Erk1/2) with a pEC50 of $11.6 \mathrm{nM}$, and also in increasing ECAR with efficacy similar to that of reference agonist, zinterol [79]. The low affinity for rat $\beta_{3}$-AR might render L748337 not fully suitable for experimental studies on the receptor [78]. Furthermore, the difference in its affinity for the human and rat receptors suggests that it may be useful in mapping the receptor's antagonist binding sites and exploring its structure-function relationships. Thus, L748337 is currently one of the very few antagonists with good selectivity for human $\beta_{3}$-AR on the market.

\section{4. $\beta_{3}-\mathrm{AR}$ as Therapeutic Target}

Since its discovery in the late 1980s, $\beta_{3}$-AR has been detected in several human tissues such as myocardium, retina, myometrium, adipose tissue, gallbladder, brain, urinary bladder, and blood vessels. Its expression has been recorded both at the mRNA and protein levels, and its activation involves a variety of cellular pathways. A recent comprehensive quantitative analysis of the human transcriptome reported $\beta_{3}$-AR expression to be far more restricted than previously hypothesized [80]; however, significant findings continue to be published. In the following sections, major tissues in which $\beta_{3}$-AR expression has been studied so far, their associated signaling pathways and clinical implications in humans will be discussed. Table 2 and Figure 1 summarize the data reported in this section. 
Table 2. Main tissues of $\beta_{3}$-AR expression with relative downstream signaling and current uses in clinical therapy.

\begin{tabular}{|c|c|c|c|c|c|c|c|c|}
\hline Tissue & & Protein & mRNA & Function & $\begin{array}{c}\text { Downstream Signaling } \\
\text { (Mediators) }\end{array}$ & $\begin{array}{l}\text { Potential Therapeutic } \\
\text { Indications }\end{array}$ & $\begin{array}{c}\text { Agonists Currently } \\
\text { Developing }\end{array}$ & Status \\
\hline \multirow[t]{2}{*}{$\begin{array}{l}\text { Urinary } \\
\text { System }\end{array}$} & Bladder & Yes & Yes & Bladder relaxation & $\mathrm{G}_{\mathrm{s}}(\mathrm{cAMP} / \mathrm{PKA})$ & $\begin{array}{l}\text { Treatment of Overactive } \\
\text { bladder syndrome }\end{array}$ & $\begin{array}{l}\text { Mirabegron } \\
\text { Solabegron } \\
\text { Vibegron }\end{array}$ & $\begin{array}{l}\text { Approved } \\
\text { Phase II } \\
\text { Phase III }\end{array}$ \\
\hline & Kidney & Yes & Yes & $\begin{array}{l}\text { Water and solute } \\
\text { reabsorption }\end{array}$ & $\mathrm{G}_{\mathrm{s}}(\mathrm{cAMP} / \mathrm{PKA})$ & - & - & - \\
\hline \multirow{2}{*}{$\begin{array}{l}\text { Central Nervous } \\
\text { System }\end{array}$} & Brain & No & Yes & $\begin{array}{c}\text { Increase of trp and } \\
\text { 5-HT levels }\end{array}$ & - & Antidepressants & $\begin{array}{l}\text { Amibegron } \\
\text { (SR58611A) }\end{array}$ & Discontinued \\
\hline & Retina & Yes & Yes & $\begin{array}{l}\text { Endothelial cell growth, } \\
\text { migration, and elongation }\end{array}$ & $\begin{array}{c}\text { MAPK cascade, } \\
\text { metalloproteinases 2/9, } \\
\text { PKG }\end{array}$ & - & - & - \\
\hline Adipose tissue & & Yes & Yes & Lipolysis, thermogenesis & $\begin{array}{c}\mathrm{G}_{\mathrm{s}}(\mathrm{cAMP} / \mathrm{PKA}) \text { and } \\
\mathrm{G}_{\mathrm{i}}(\mathrm{NO})\end{array}$ & $\begin{array}{l}\text { Anti-obesity, } \\
\text { anti-diabetic }\end{array}$ & Beta-phenylethylamine & Pre-clinical \\
\hline Myocardium & & Yes & Yes & $\begin{array}{l}\text { Lowering/Increasing of } \\
\text { cardiac contractility }\end{array}$ & $\begin{array}{c}\mathrm{G}_{\mathrm{i}}(\mathrm{NO}) / \\
\mathrm{G}_{\mathrm{s}}(\mathrm{cAMP} / \mathrm{PKA})\end{array}$ & $\begin{array}{l}\text { Treatment of } \\
\text { heart failure }\end{array}$ & $\begin{array}{c}\text { Mirabegron } \\
\text { (repurposing study) }\end{array}$ & Phase II \\
\hline Myometrium & & Yes & Yes & $\begin{array}{c}\text { Relaxation of } \\
\text { myometrial contractions }\end{array}$ & cAMP & $\begin{array}{l}\text { Management of } \\
\text { preterm labor }\end{array}$ & - & - \\
\hline
\end{tabular}




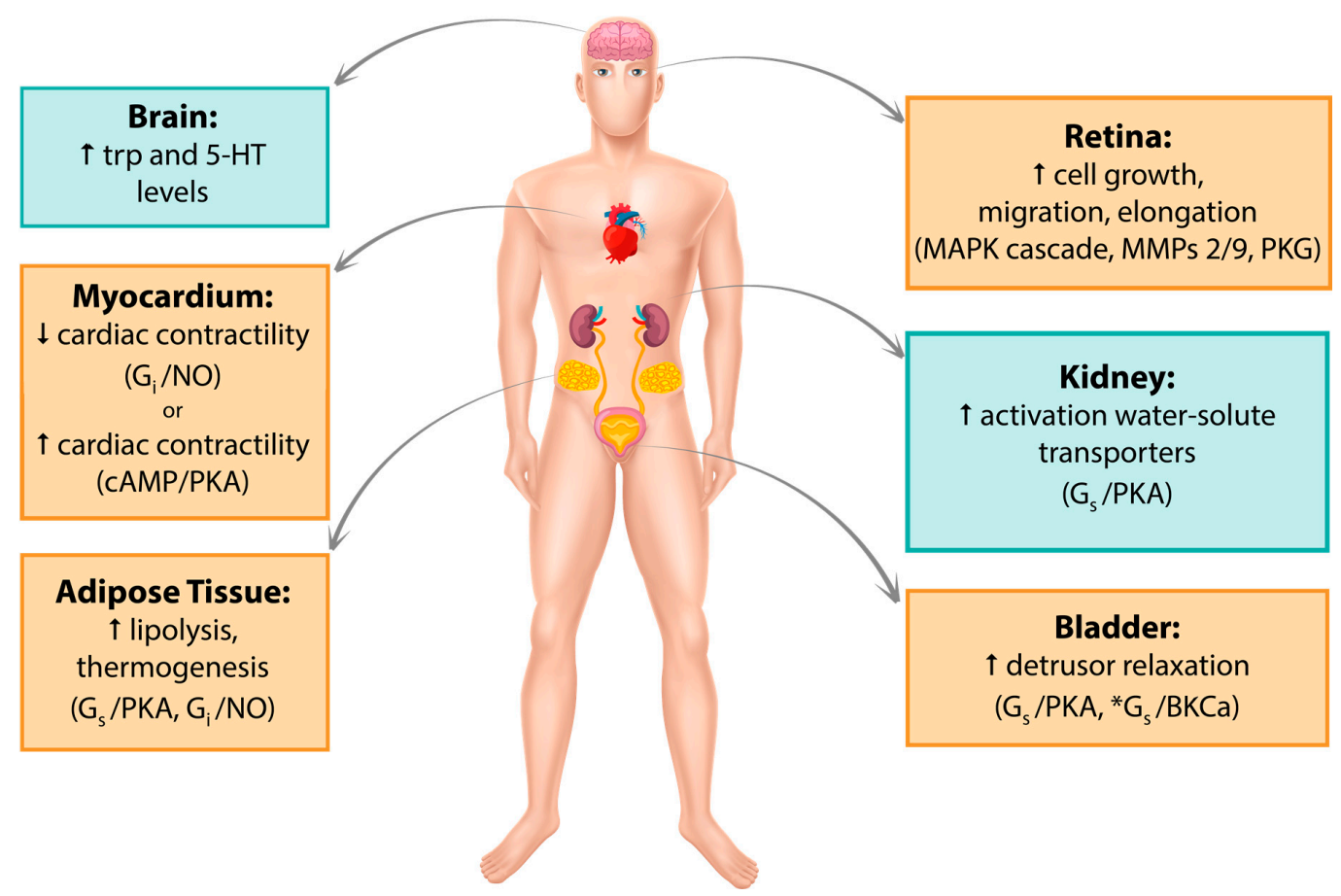

Figure 1. Graphic summary of $\beta_{3}$-AR localization. Pathways that have been studied and reported in human tissue/cell lines are in yellow boxes. Pathways studied in mouse but not yet found in humans are in blue boxes. *Alternative cAMP-independent pathway. Trp, tryptophan; 5-HT, 5-hydroxytryptamine; MAPK, mitogen-activated protein kinase; MMPs, metalloproteinases, PKG, protein kinase G; NO, nitric oxide; PKA, protein kinase A.

\subsection{Urinary System}

$\beta_{3}$-AR has been localized in kidneys [3] and in the lower urinary tract [81] including ureters [82], urethra [83], prostate [84], and bladder [85] where it appears to be the predominant subtype [86] although this idea was recently challenged in a wide transcriptomics analysis across several human tissues [80].

The presence of an atypical $\beta$-receptor in human detrusor was first suggested in the 1970s $[1,87]$ and was confirmed by evidence that muscle relaxation in pre-contracted samples could not be evoked by stimulation with $\beta_{1}$ - and $\beta_{2}$-AR agonists but only with $\beta_{3}$-AR agonists such as BRL37344A. Consistently, $\beta_{3}$-AR antagonists SR58894A and L748337 both induced a rightward shift in the concentration-relaxation curve of isoproterenol-treated detrusor muscle preparations [54,88]. The presence of $\beta_{3}$-AR transcript was first reported in human detrusor smooth muscle cells [88] while the protein was found later on in the detrusor and urothelium [85]. Determination of the relative abundance of each one of the three $\beta$-AR in the bladder muscle by quantitative analysis revealed $\beta_{3}$-AR mRNA to be the most represented $(97 \%)$ against $1.5 \%$ and $1.4 \%$ of $\beta_{1}$ - and $\beta_{2}$-AR respectively [86]. However, the physiological significance of this result is limited as the tissue mRNA concentration does not necessarily correlate with the protein level.

As for the $\beta_{3}$-AR signaling pathway in the bladder, several different and not always consistent hypotheses have been offered. Beta adrenergic signaling often relies on the cAMP/PKA pathway [89-91] and cAMP is a key player in smooth muscle relaxation, however the extent of its involvement in this process is still a matter of debate. Stimulation of non-contracted muscle strips with the $\beta_{3}$-AR agonist FR165101 have been shown to induce a concentration dependent decrease in muscle basal tension and an increase in the cAMP levels. Furthermore, pre-incubation with adenylate cyclase inhibitor SQ22536 markedly suppressed both of these effects [92]. However, Maki et al. recently reported a milder effect of SQ22536 on human and pig pre-contracted detrusor strips treated with mirabegron supporting the hypothesis of a cAMP-independent mechanism, potentially via activation of myosin light chain phosphatase [93]. Along the same line, Frazier et al. previously showed that only Rp-cAMPS, among 
other PKA inhibitors had a small significant effect on isoproterenol responses against passive tension on non-contracted rat bladder strips, not supporting a major role for cAMP and/or PKA in $\beta$-AR-mediated bladder relaxation. They hypothesized an alternate signaling pathway involving a direct interaction of $\beta$-AR, or its linked Gs, with a different partner such as the large conductance $\mathrm{Ca}^{2+}$ activated $\mathrm{K}^{+}$ channel (BKCa) [94]. Both Uchida and Frazier showed that BKCa selective block had a negative effect on isoproterenol-stimulated pre-contracted rat bladder strips. In conclusion, these studies support a potential, and somewhat partial role, for CAMP/PKA pathway in $\beta$-adrenergic-mediated relaxation from passive tension of rat detrusor muscle; at the same time, they hypothesize a cAMP-independent mechanism involving BKCa channels in $\beta$-adrenergic modulation of smooth muscle active tone in the urinary bladder. Thus, the contribution of the two mechanisms seems to be dependent on the condition of the detrusor muscle. Additionally, D'Agostino et al. used electrical field stimulation (EFS) to show that $\beta_{3}$-AR activation strikingly inhibits EFS-evoked contraction and acetylcholine (Ach) release from cholinergic nerves in a concentration-dependent manner in human detrusor bladder strips [45]. The fact that BKCa channel activation at prejunctional sites has a hyperpolarizing effect on parasympathetic nerve terminals [95] and that they are potentially involved in $\beta_{3}$-AR signaling [92,94] might explain how $\beta_{3}$-AR stimulation reduces neurotransmitter release. $\beta_{3}$-AR modulation of ACh release is also supported by a recent immunohistochemistry study showing $\beta_{3}$-AR expression on the detrusor cholinergic fibers in close proximity to sympathetic bundles innervating the human bladder. This arrangement is physiologically logical, as adrenergic fibers can release noradrenalin necessary to activate $\beta_{3}$-AR [96].

Scarce and controversial information regarding $\beta_{3}$-AR presence in the kidney has been reported up to date, with some publications describing functional and transcriptional evidence [97-99] while some others fail to report its presence at all [80]. Recently, we provided evidence regarding the localization of $\beta_{3}$-AR to the vasopressin-sensitive segments of the mouse nephron. The agonist BRL37344 was used on freshly isolated kidney tubules and slices from wt and $\beta_{3}$-AR knock out (KO) mice to demonstrate $\beta_{3}$-AR coupling to Gs/adenylyl cyclase and its positive effects on key water and solute transporters, such as Aquaporin 2 (AQP2) and Na-K-2Cl (NKCC2). All effects reported were blocked upon pre-incubation with the antagonist L748337 or PKA inhibitor H89, suggesting a potential activation of the cAMP/PKA axis. Ex vivo findings are strengthened by in vivo data, showing that $\mathrm{KO}$ mice for $\beta_{3}-\mathrm{AR}$ are mildly polyuric and highlighting a role for $\beta_{3}-\mathrm{AR}$ in renal homeostasis. Interestingly, administration of BRL37344 to a mouse model of X-linked nephrogenic diabetes insipidus (NDI), known to be heavily polyuric, completely reverted the phenotype within $1 \mathrm{~h}$ from injection [3]. In light of these findings, it is tempting to speculate on the use of $\beta_{3}$-AR as therapeutic target in conditions where water-solute homeostasis and/or vasopressin signaling are impaired (see Section 6).

$\beta_{3}$-AR are also present in the lower urinary tract where they undergo pathophysiological changes in expression upon the initiation of lower urinary tract symptoms due to ureteral stenosis [82], chronic kidney disease, end stage renal disease, or certain carcinomas [100]. The $\beta_{3}$-AR agonist mirabegron for the oral pharmacotherapy of patients affected by overactive bladder syndrome $(\mathrm{OAB})$ is currently the most promising agent in over 30 years. This drug has been extensively studied, with a good number of Phase II and Phase III trials all over the world, exhibiting a good balance between efficacy and tolerability in all of them [7]. It was licensed for the treatment of OAB and approved for use in Japan in 2011 (Betanis), USA and Canada in 2012 (Myrbetriq), and Europe in 2013 (Betmiga). Safety and tolerability of mirabegron in the treatment of OAB have been extensively reviewed by Michel et al. [101]. Several repurposing studies are currently exploring potential uses for mirabegron in the treatment of heart and metabolic conditions. Other molecules have made it to Phase III clinical trials: ritobegron however appears to have been discontinued (Clinicaltrials.gov, NCT01003405) while the new potent and selective $\beta_{3}$-AR agonist, vibegron, has recently passed the later stages [47] and has been approved in Japan for the treatment of OAB [46]. 


\subsection{Adipose Tissue}

$\beta_{3}$-AR is abundantly expressed in rodent white (WAT) and brown (BAT) adipose tissue where it mediates lipolysis and thermogenesis [13,102]. In humans, $\beta_{3}$-AR mRNA levels appeared to be much lower in these tissues. The transcript was mainly identified in infant peri-renal BAT and in various deposits of WAT in the adults $[18,103]$ while its presence at the protein level was published later through the use of a monoclonal antibody directed against the human receptor [104,105]. Of note, one of the greatest obstacles in the study of $\beta_{3}$-AR role and function in humans is represented by the little presence of BAT in adults; however, studies in the last decade are overturning these findings, showing proof for a metabolic role of BAT in healthy adults $[106,107]$. Similarly, to rodents, selective activation of $\beta_{3}$-AR stimulates lipolysis in human isolated white adipocytes $[108,109]$.

A major trigger of both lipolysis and thermogenesis is the sympathetic nervous system. From a molecular point of view, noradrenaline (NA) released by sympathetic nerve endings binds to $\beta_{3}-A R$, which couples to the $\alpha$-subunit of Gs-proteins and triggers the activation of the cAMP-PKA axis. Final targets of this cascade include lipid droplet proteins, like hormone-sensitive lipase (HSL) and perilipin, that start the lipolytic process in white adipocytes. However, $\beta_{3}$-AR signaling in adipocytes is promiscuous in that HSL activation can also be triggered by $\beta_{3}$-AR coupling to Gi and consequent initiation of the ERK1/2 MAP kinase cascade [110,111]. The net result is the release of free fatty acids (FFAs) derived from the hydrolysis of triglycerides stored in the lipid droplet. In brown adipocytes FFAs activate Uncoupling-Protein 1 (UCP1) in the mitochondria, triggering thermogenesis. Of note, $\beta_{3}$-AR activation can also lead to lipolysis by increasing the transcription/expression of the inducible nitric oxide synthase (iNOS) and thus nitric oxide levels in a PKA-dependent fashion [112].

$\beta_{3}$-AR activation was recently found to be involved in the generation of hyperthermia arising from WAT, instead of the more classically thermogenic BAT, with simultaneous WAT remodeling and increased beiging in mice with impairment in triglyceride storage capabilities [5]. $\beta_{3}$-AR KO mice also showed impaired cold-induced thermogenesis with a reduction in white adipocyte beiging [113]. This is consistent with recent findings that $\beta_{3}$-AR activation induces trans-differentiation of mature white adipocytes but that cold-induced beiging occurs via $\beta_{1}$-AR [114]. In contrast, others argued that $\beta_{3}$-AR is dispensable for thermogenesis, showing that adaptive response to cold is not affected in KO mice [115].

Regardless of these effects, $\beta_{3}$-AR KO mice lack a major phenotype, with only moderate fat accumulation in females vs. males and no altered adipose-related functional response to $\beta$-agonists [116]. KO mice also show a compensatory over-expression of $\beta_{1}$-AR in WAT and BAT and they are able to survive cold exposure through $\beta_{1}$-AR mediated thermogenesis and UCP1 increase [116,117]. More recent findings, however, reported that $\beta_{3}$-AR KO mice generated on the same background show an increased susceptibility to high fat diet, developing more severe obesity with white adipocyte hypertrophy and inflammation in comparison to wild type mice [118]. Consistently, Hong at al showed that the ERK- $\beta_{3}$-AR axis is a key player in obesity-driven increases in lipolysis and that administration of MEK inhibitors is efficient in blunting both in vivo lipolysis in diet-induced obese mice and ex vivo lipolysis induced by $\beta_{3}$-AR agonist treatment on human and murine WAT explants [119].

Lipid and carbohydrate metabolism are influenced by $\beta_{3}$-AR agonists with normalizing effects on hyperinsulinemia, increases in resting energy expenditure (REE) and decreases in circulating FFAs, fat/non-fat mass ratio and body weight gain in rats or in obese mice $[4,120,121]$. In humans, $\beta_{3}$-AR expression level is reduced in obese patients [105]. These observations raised interest in the development of compounds for the treatment of obesity and type 2 diabetes [122,123], but clinical studies $[124,125]$ were disappointing due to poor selectivity of the drugs for the human $\beta_{3}-\mathrm{AR}$ and different contributions of white and brown adipocytes in rodents and humans [126].

No agonist has yet progressed beyond phase II clinical trials. It is unclear whether this is because of the lack of compounds with suitable drug properties (e.g., oral bioavailability), because of a lesser role for $\beta_{3}$-AR in modulating adipogenesis in humans than in rodents or due to the little presence of BAT in adults, although this concept has been challenged in the last decade $[106,107]$. However, there is still 
active speculation in regard to $\beta_{3}$-AR as a target for metabolic conditions. A short review by Jonathan Arch. discusses this long-standing issue, proposing some alternatives like combined administration of $\beta_{3}$-AR agonists and other compounds aimed at increasing BAT amount in patients [127]. A recent study investigated the repurposing of mirabegron, determining its ability to stimulate BAT activity and REE in healthy subjects [9]. Despite study limitations of size and gender, these findings show that administration of supra-therapeutic doses of mirabegron leads to an increase in REE via cardiovascular stimulation and BAT activation but also causes unwanted cardiovascular effects, likely due to $\beta_{1}$-AR off-target binding. Finally, even in cases where weight reduction is not achieved, $\beta_{3}$-AR stimulation could generally exert positive metabolic effects [9]. This study might contribute to the re-opening of a debate about $\beta_{3}$-AR role as a possible candidate for the treatment of obesity and metabolic diseases, highlighting the necessity for the development of more subtype-selective agonists so as to limit side effects to a minimum.

Along the same line and based on all these pre-clinical and clinical considerations, new beta-phenylethylamine compounds were recently synthetized and tested in rats with alloxan-induced type II diabetes. All of these compounds markedly decreased levels of total cholesterol, LDL cholesterol, and triglycerides and increased the values of antiatherogenic HDL cholesterol. Moreover, the effects were significantly more intense than the reference substance BRL37344 [128]. In light of these considerations it appears that, although theoretically appealing, the amount of data that is currently available is not enough for $\beta_{3}$-AR agonists to proceed into a clinical stage and more insights into the receptor physiology are ultimately needed for this purpose.

\subsection{Myocardium}

The presence of $\beta_{3}$-AR transcript $[103,129]$ and protein $[104,105]$ in cardiac tissue was described in the early 1990s in both atria and ventricles. However, reports varied significantly depending on the portion of cardiac tissue considered with some failing to identify any transcript in ventricles at all [130]. Significant inter-species differences have also been observed in response to $\beta_{3}$-AR activation [131]. In line with the purpose of this work, only effects in humans and rodents will be reviewed in this section. In human ventricles, $\beta_{3}$-AR was shown to exert a marked negative inotropic effect upon stimulation with agonists such as BRL37344, amibegron, and CL316243. However, these compounds were shown later on to exert non-specific effects through $\beta_{1}$ - and $\beta_{2}$-AR [132]. Since this effect was attenuated by pre-treatment with the pertussis toxin, it was attributed to a potential coupling with Gi proteins through an as yet unknown mechanism [129]. Among the pathways involved in cardiac contractility, the nitric oxide (NO) pathway plays a role in decreasing cardiac contraction upon activation of the autonomic nervous system. Indeed, the effect of $\beta_{3}$-AR stimulation on cardiac contractility is abrogated by pre-incubation with either a non-specific NO blocker or a nitric oxide synthase (NOS) inhibitor and treatment with BRL37344 induces an increase in both NO and cGMP, known mediators of the NO pathway. The NOS isoform most likely involved is the endothelial NOS (eNOS), abundantly expressed in human cardiac myocytes [133]. The effect of NO, endogenously-produced by eNOS on cardiac contractility, in human myocytes is consistent with data obtained in other species [134-136]. However, $\beta_{3}$-AR can also modulate NO signaling via neuronal NOS (nNOS) $[137,138]$. Interestingly, the signaling through the downstream Gi/NOS pathway involves increases in intracellular cGMP, which are sensitive to NOS inhibitors and protein kinase G (PKG) activation [139]. Functional evidence for a NO-cGMP-PKG pathway leading to ventricular relaxation in rats has been discussed by Angelone et al. that showed how treatment with hemoglobin (a NO scavenger), L-NMMA (a NOS inhibitor), or ODQ (a soluble guanylate inhibitor) abolished the effect of BRL37344 [140]. Unexpectedly, another study showed a positive inotropic effect and a stimulation of L-type Ca2 ${ }^{+}$channel-mediated current $\left(I_{\mathrm{Ca}-\mathrm{L}}\right)$ in isolated human atrial myocytes upon $\beta_{3}$-AR stimulation with BRL37344 and partial agonist CGP12177. These effects were neither due to Gi nor to NOS activation but were instead mediated by a cAMP/PKA pathway, as pre-incubation with the selective PKA inhibitor H89 abolished them completely [141]. However, according to Christ et al., the BRL37344-mediated increase in contractility elicited in human 
right atrial appendages is attributable to $\beta_{1}$ - and $\beta_{2}$-AR stimulation. This is possible because BRL37344 has been reported to induce preferential activation of $\beta_{2}$-AR in human atria and its effect is only mildly antagonized by $\mathrm{L} 748337$ while it is heavily blunted by $\beta_{2}$-AR (and $\beta_{1}$-AR) antagonists [142]. Some other studies completely failed to show any inotropic effect in human ventricular muscle samples although confirming a positive coupling between $\beta_{3}$-AR stimulation and $I_{\mathrm{Ca}-\mathrm{L}}$ in both atrial and ventricular chambers [143]. Of note, these data have to be interpreted carefully taking into account the poorly defined pharmacology of the receptor, which may give rise to selectivity problems between isotypes. Additionally, a major limitation of these studies often lies in fact the agonist-induced effects are not corroborated by antagonist stimulations and/or achieved with the administration of a single concentration of drug. Indeed, the negative inotropic effect elicited by low concentrations of CL316243 and amibegron in human ventricles [129], vanishes at higher concentrations [132]. A thorough review of $\beta_{3}$-AR role in the human myocardium and all the hidden dangers in the interpretation of its pharmacology has been recently published by Arioglu-Inan and colleagues [144]. If on the one hand, $\beta_{3}$-AR partial responses in the myocardium might suggest that the therapeutic use of $\beta_{3}$-AR agonists does not pose a risk to cardiac function; on the other, Mo et al. recently reported that mirabegron exerts both a cardiostimulant and a cardiodepressant effect seemingly unrelated to $\beta_{3}$-AR activation. In this study, stimulation of human right atrial appendages with mirabegron caused an increase in contractile force that was not only antagonized, but even reversed to negative inotropy upon incubation with $\beta_{1}$-AR blocker CGP20712A. However, neither effect was influenced by treatment with $\beta_{3}$-AR antagonist L748337. Besides discrediting a role for $\beta_{3}$-AR in mediating cardiac inotropy the authors also point out that, given mirabegron structure, a direct interaction with $\beta_{1}$-AR is rather unlikely in favor of a more indirect action as a sympathomimetic drug. Indeed, preincubation of the samples with neuronal uptake blockers induces the same negative inotropic effect achieved with CGP20712A [145]. It is, indeed, of the utmost importance that such studies are taken into account during the optimization and design of future $\beta_{3}$-AR agonists intended for clinical use.

The $\beta_{3}$-AR signaling pathway in human myocardium can thus be summarized as follows: its stimulation leads to the activation of eNOS or nNOS, probably by means of Gi protein, increasing NO production; NO, in turn, activates a soluble form of guanylate cyclase leading to cGMP production followed by PKG activation that ultimately enhances myocyte relaxation and causes negative inotropy, possibly through the phosphorylation of troponin I, phospholamban, and L-type Ca2+ channels [146]. However, $\beta_{3}$-AR downstream signaling the heart might also involve L-type $\mathrm{Ca}^{2+}$ channels stimulation through a cAMP/PKA mechanism leading to positive inotropy at least in human atria [141]. Finally, despite coupling with L-type $\mathrm{Ca}^{2+}$ channels, some studies fail to show any effect on inotropy at all $[143,144]$

Hence, $\beta_{3}$-AR produces a negative inotropic effect in the human myocardium that is more pronounced in ventricles than in atria and opposite to the one mediated by $\beta_{1}$ - and $\beta_{2}$-AR. Unlike the other two isotypes, $\beta_{3}$-AR is expressed at a low level in the normal heart but several reports showed changes in its expression levels at both protein and transcript level in pathophysiological conditions such as diabetes, heart failure, sepsis, and myocardial fibrosis [147-150]. Due to this overexpression and its low tendency to desensitization, $\beta_{3}$-AR is considered to be a promising therapeutic target for cardiac conditions. For instance, both nebivolol and metoprolol, FDA-approved $\beta_{1}$-selective blockers, have been shown to exert their cardio-protective effects via $\beta_{3}$-AR $[151,152]$. On the one hand, $\beta_{3}$-AR could serve as a 'safety valve' at the high levels of sympathetic stimulation typical of cardiac conditions; on the other, its cardio-depressant effect might become maladaptive during later stages and lead to further myocardial dysfunctions. $\beta_{3}$-AR antagonists and especially agonists have been proposed as potential strategies for treatment or prevention of heart failure and of ischemic damage [136,149]. It was shown that activation of the $\beta_{3}$-AR-PKG signaling cascade inhibits hypertrophy in transgenic mice models with cardiac specific expression of the human receptor and that selective $\beta_{3}$-AR stimulation confers protection in the failing heart through a specific cGMP/NO signaling pathway [153]. NO has also been associated with the enhancement of endothelial cell proliferation [154] that can have a beneficial 
effect on cardiac function and remodeling within the failing myocardium [155]. Recently, the same mouse model was used to show that the presence of functional $\beta_{3}$-AR in the heart attenuates cardiac hypertrophy via the activation of nNOS. This effect is exerted through paracrine mediators secreted by $\beta_{3}$-AR-expressing cardiac myocytes that ultimately attenuate the pro-fibrotic phenotype in cardiac fibroblast [147].

Based on all the pre-clinical evidence discussed above, two clinical trials, the "Beta 3 Agonist Treatment in Heart Failure" (Beat-HF; clinicaltrials.gov: NCT01876433) and the "Assessment of Efficacy of Mirabegron, a New Beta 3-Adrenergic Receptor in the Prevention of Heart Failure" (Beta3_LVH; clinicaltrials.gov: NCT02599480), are evaluating the effects of $\beta_{3}$-AR agonism on HF progression and development (commented on in [8]).

\subsection{Brain}

Antidepressant effects mediated by a so-called atypical $\beta$-receptor in rat brain [41], but attributed by some to $\beta_{1}$-AR [156], were described in the early 1990s. The expression of $\beta_{3}$-AR mRNA in the rat brain [61] and in different regions of the human brain such as frontal cortex and hippocampus [60] was reported a little later. Given the fact that brain $\beta$-ARs are involved in the regulation of depressive states [157], Stemmelin et al. conducted a study on "the first selective, orally active and brain-penetrant $\beta_{3}$-AR agonist", amibegron, with high efficacy and potency at the rat and human $\beta_{3}$-AR, demonstrating its robust anxiolytic-like effects in rats [64]. Indeed, treatment with amibegron increased tryptophan and consequently 5-hydroxytryptamine (5-HT) levels via activation of peripheral $\beta_{3}$-AR in several areas of rat brain and also NE release via activation of central $\beta_{3}$-AR probably located in the locus coeruleus, [158]. Other studies suggested the involvement of neurotrophic or anti-apoptotic factors and interactions with serotonin 5-HT1A, 5-HT2A, and 5-HT3 receptors in the $\beta_{3}$-AR-mediated antidepressant effect $[159,160]$. Amibegron has been investigated through several clinical trials in 2007 but Sanofi has discontinued its clinical development for the time being due to lack of efficacy [40].

$\beta_{3}$-AR is also densely expressed in the murine hippocampus [161] where it acts to modulate glucose uptake. It has consistently been shown to be involved in memory consolidation, a process that relies both on modulation of hippocampal neuron excitability and activation of brain glucose metabolism. Church et al. recently described a role for $\beta_{3}$-AR in regulating the action potential firing of hippocampal pyramidal neurons via a cAMP-independent pathway involving hyperpolarization-activated cyclic nucleotide gated channels [162]. Gibbs et al. showed that memory formation at the time of learning is enhanced by the administration of $\beta_{3}$-AR agonist CL316243 to day-old chicks, a process most likely due to an increase in glucose uptake via GLUT3 [163]. Interestingly, $\beta_{3}$-AR KO mice show a decrease in mRNA level of GLUT3 transporter in the amygdala and impairments in long- and short-term memory formation [164].

Finally, $\beta_{3}$-AR has also been implicated in the generation of neuropathic pain as the mediator of ATP release from dorsal root ganglia neurons upon NE stimulation [165]. Recent studies further showed that only peripheral $\beta_{3}$-AR are involved in the generation of pain and neuroinflammation by eliciting an increase in the release of pro-inflammatory cytokines such as TNF $\alpha$ and Interleukin $1 \beta$ [6]. Given these considerations and the fact that $\beta$-blockers are already widely used in several areas of clinical treatment, some studies are seeking ways to include them in pain management [166].

\subsection{Retina}

$\beta_{3}$-AR also exerts vasorelaxant and antiangiogenic effects in rodent retinal blood vessels [167]. Protein expression in human retina was first detected in cultured retinal endothelial cells where targeted stimulation with BRL37344 promoted cellular growth and migration [168]. A targeted approach via selective inhibition showed that the $\beta_{3}$-AR pro-proliferative effect is likely mediated by a signaling cascade involving mitogen-activated protein kinase (MAPK) pathway components rather than by the cAMP/PKA axis, while $\beta_{3}$-AR induced cell migration relies instead on a Src-PI3K pathway. Interestingly, functional studies on human choroidal cells showed that $\beta_{3}$-AR stimulation evoked a substantially 
lower proliferative response in these cells compared to retinal endothelial cells and that this is likely mediated by PKG [169]. Rodent models are currently used to investigate a potential role for $\beta_{3}$-AR as a therapeutic target in retinopathies [170]. In retinal vascularization-associated diseases, hypoxia plays a large role in triggering neoangiogenesis through vascular endothelial growth factor (VEGF) release. Dal Monte et al. studied $\beta_{3}$-AR regulation of VEGF production in mouse retinas, showing that $\beta_{3}$-AR protein levels are increased in hypoxic retinas and that siRNA silencing of the receptor blunts hypoxia-induced VEGF increase [171]. $\beta_{3}$-AR stimulation with BRL37344 significantly increased VEGF release in hypoxic retinas vs. normoxic and untreated hypoxic samples. Conversely, its blockade prevented VEGF increase in the same hypoxic conditions, suggesting a potential role for $\beta$-blockers in the treatment of retinal diseases. However, given the physiological role of VEGF as a growth factor, it has to be taken into account that changes in its levels could be associated with cell death as reported by Casini et al. 2014 [71]. Strikingly, non-selective inhibition of nitric oxide synthase (NOS) abolished BRL37344-induced VEGF increase while supplementation of NO bypassed the beneficial effect of $\beta_{3}$-AR blockade, pinpointing NO as a key downstream effector in this pathway. Of note, expression of the inducible isoform of NOS (iNOS) is not only unaffected by $\beta_{3}$-AR stimulation but even reduced upon $\beta_{1}$-AR activation in human retinal endothelial cells [172], suggesting that the $\beta_{3}$-AR effect in human retina could involve different NOS isoforms such as eNOS or nNOS, as in the myocardium $[137,138]$ and that data extrapolation between human and rodents should be evaluated carefully.

\subsection{Cancer Therapy}

The presence of $\beta_{3}$-AR mRNA and protein has been reported across different tumors, including vascular tumors, colon and breast cancer, and human leukaemia cells [173-177] and the Trp64Arg polymorphism may be associated with an increased susceptibility to some cancers (see Section 5). In particular, $\beta_{3}$-AR presence is detected at very high levels in human melanoma sections $[99,176]$. This is not surprising considering that $\beta$-ARs have been found at many sites of tumor growth and metastasis, where they are involved in multiple cellular processes that contribute to the initiation and progression of cancer [178]. Of note, Dal Monte et al. published a study elucidating the potential role for $\beta_{3}$-AR in the context of melanoma. They showed that $\beta_{3}$-AR blockade increases apoptosis and reduces tumor cell proliferation and vascularization, thereby slowing down melanoma growth in treated mice [179]. Importantly, the overall levels of pro-angiogenic factors were not affected by $\beta_{3}$-AR blockade, suggesting that the reduced tumor vascularization is probably due to the increase in apoptosis and that the chance of systemic side-effects is minimal. $\beta_{3}$-AR was also shown to enhance the proliferative advantage of tumor cells by promoting a metabolic shift towards aerobic glycolysis, known as the Warburg effect, in melanoma stem cells. Notably this effect is reverted by SR59230A treatment [180]. Another very recent report by the same group further describes a role for $\beta_{3}$-AR as immune-modulator agent in melanoma. In the study, the authors show that $\beta_{3}$-AR antagonism with SR59230A and siRNA injections reduces melanoma growth in vivo. This effect is due to an increase in the number of natural killer cells (NK) and CD8 T cells (CD8) as well as their cytotoxicity, and to the abrogation of the immune-suppressive cells, the so-called myeloid-derived suppressor cells (MDSC) and regulatory T cells (Treg), in the tumor microenvironment [181]. Thus, the authors showed for the first time the involvement of $\beta_{3}$-AR in immune-tolerance, reinforcing the hypothesis that its targeting could actually represent an effective therapy to overcome melanoma growth. In addition to cancer cells $\beta_{3}$-AR is highly expressed in stromal, inflammatory, and vascular cells of the melanoma microenvironment where it favors melanoma aggressiveness through recruitment of stromal cell precursor to the tumor site and induction of inflammatory cytokines secretion and de novo angiogenesis [176]. A comprehensive review recapitulating the state-of-the-art of preclinical findings on $\beta_{3}$-AR role in melanoma has recently been published by Dal Monte et al. [182]. Main limitations of the present studies are the ill-defined pharmacological profile of the receptor and important inter-species differences that hamper the extrapolation of animal data for human applications. 
Besides the limitations described above these results may still lead the way to further explorations $\beta_{3}$-AR in cancer therapy or at least in melanoma treatment.

\section{Polymorphisms}

Each $\beta$-AR is known to have some commonly recognized polymorphisms in humans (for review, see [183]). Early studies in French patients and Pima Indians reported a recurring genetic variation in the $\beta_{3}$-AR gene that yields a Trp64Arg substitution at the intracellular end of TM1 $[184,185]$. Homozygotes for Trp64Arg exhibited increased tendency to gain weight and earlier onsets of type 2 diabetes. This mutation occurs with an approximate frequency of $8-10 \%$ in the Caucasian population, $20 \%$ in the Japanese population, and $40 \%$ in Alaskan Eskimos [186]. A correlation between Trp64Arg and type 2 diabetes, likely dependent on ethnicity, has been described in a recent meta-analysis [187]. The presence of Trp64Arg was also reported to influence metabolic parameters such as LDL-C [10] and HDL-C [11] accumulation rates and resistance to weight loss in cohorts of Brazilian and Japanese patients, respectively. Consistently, Trp64 polymorphism correlates with increases in Body Mass Index [188] and has a weak but significant influence on carriers leading to greater fat mass and percentage [189]. A stronger case was recently made in a larger patient cohort of Saudis, where Trp64Arg was linked to dyslipidemias and body weight gain [190]. $\beta_{3}$-AR has a prominent role in the human bladder [86]. A meta-analysis of two case-control studies including 419 patients identified that both homozygous and heterozygous carriers of the polymorphism were associated with the occurrence of OAB [191]. However, the association between Trp64Arg and metabolic alterations is controversial, with some studies reporting no correlation between the two [192,193]. For example, Teitsma and colleagues did not detect any significant association between Trp64Arg and lower urinary tract function in a cohort of more than 1000 men [194], although Trp64Arg allele was reported to be significantly more frequent in subjects with OAB (57\%) than in those without (23\%) [195]. The discrepancies between these two studies could be due to inclusion criteria. Also, Trp64Arg is clinically considered to encode a hypofunctional variant of the receptor, possibly associated with a reduced bladder compliance. Hence, it is possible to argue that a functional relevance of the polymorphism would become clearer in situations when the receptor is activated, such as OAB. For this reason, a statistically significant association between Trp64Arg and OAB would be more easily detectable than one between Trp64Arg and milder lower urinary tract alterations. Finally, $\beta_{3}$-AR polymorphism Trp64Arg has been recently studied in relation to urate and gout with a positive ethnicity-dependent correlation [196], and in relation to breast, endometrial, and gallbladder cancer [197-199] in association with an increased susceptibility.

\section{Conclusions}

The therapeutic approaches described herein are only some of the ways $\beta_{3}$-AR has yet been targeted. More are still under development and need to be explored. For instance, $\beta_{3}$-AR mRNA and protein expression were surprisingly reported in the female reproductive system (ovaries, placenta, and Fallopian tubes) as one of the highest hits in a recent comprehensive quantitative analysis of the human transcriptome [101]. Although the role of $\beta_{3}$-AR in such tissues remains unclear, its presence and function in human near-term myometrium was previously described and specific stimulation of the receptor caused marked relaxation of myometrial contractions via a cAMP/PKA mechanism [200,201]. Such findings led to the suggestion of a potential role for $\beta_{3}$-AR in the management of preterm labor and of its involvement in chronic inflammatory diseases. It is a known fact that inflammation is one of the regulators of preterm labor. Indeed, Hadi et al. recently described how $\beta_{3}$-AR stimulation evokes a dose-dependent anti-oxidant effect that ultimately blunts inflammation in myometrial biopsies. The study also reports, for the first time, $\beta_{3}$-AR presence and anti-oxidant properties in human macrophages obtained from healthy donors [202].

Finally, as previously mentioned, $\beta_{3}$-AR can act as upstream regulator of key proteins for water and solute reabsorption. It is fair to note that the $\beta_{3}$-AR signaling pathway shares a high degree of similarity with the vasopressin pathway, leading to increases in water and solute uptake that are 
mirrored by the activation of water and solute transporters via cAMP. In addition, $\beta_{3}$-AR selective stimulation rescues AQP2 function in the absence of arginine vasopressin (AVP) action and dramatically reduces the urine volume in a mouse model of X-linked NDI [3]. Thus, this pathway may constitute a valid alternative for the treatment of conditions characterized by impairments in vasopressin signaling or vasopressin type 2 receptor (AVPR2) expression, such as NDI, polycystic kidney disease (PKD), or the syndrome of inappropriate secretion of AVP (SIADH). To further support the feasibility of a chronic treatment with $\beta_{3}$-AR agonists in vivo, we recently confirmed that human $\beta_{3}$-AR is resistant to desensitization in kidney epithelial cells and that it elicits long-lasting downstream effects on its targets, by comparing its desensitization rate to human AVPR2 upon stimulation with selective agonists [22].

The physiology and function of $\beta_{3}$-AR is rapidly being revealed, making this receptor an interesting target for novel therapeutic approaches. Its role in humans is, however, controversial and studies have suffered from the late discovery of $\beta_{3}$-AR, the consequent lack of selective detection tools, and inter-species differences. Finally, thanks to advances made over the last two decades, targeting $\beta_{3}$-AR has been proposed for the treatment of several conditions, with some drugs undergoing Phase II and III clinical trials and others already on the market. Restricted tissue expression and relative low tendency to desensitization are some of $\beta_{3}$-AR features that would allow for a prolonged pharmacological stimulation with low systemic off-target effects. Its low sensitivity to catecholamines also suggests its potential role in pathological conditions (e.g., heart disease), thereby making it even more appealing in such a context. The data reviewed here summarize the evidence that paved the way to the use of $\beta_{3}$-AR in pharmacologic treatments and that might lead to speculations on future applications of $\beta_{3}$-AR as a therapeutic target in the treatment of multiple conditions.

Funding: This work was supported by NIH grants NIH RO1 DK072612 and NIH PO1 DK-17433 both to MJC.

Acknowledgments: The authors would like to acknowledge Dwight Leone for his support with figure design. Monica Carmosino for discussion and suggestions on the topic. Aria Nouri for constant support and advice.

Conflicts of Interest: The authors declare no conflict of interest. The funders had no role in the design of the study; in the collection, analyses, or interpretation of data; in the writing of the manuscript, or in the decision to publish the results.

\section{References}

1. Nergardh, A.; Boreus, L.O.; Naglo, A.S. Characterization of the adrenergic beta-receptor in the urinary bladder of man and cat. Acta Pharmacol. Toxicol. 1977, 40, 14-21. [CrossRef]

2. Emorine, L.J.; Marullo, S.; Briend-Sutren, M.M.; Patey, G.; Tate, K.; Delavier-Klutchko, C.; Strosberg, A.D. Molecular characterization of the human beta 3-adrenergic receptor. Science 1989, 245, 1118-1121. [CrossRef]

3. Procino, G.; Carmosino, M.; Milano, S.; Dal Monte, M.; Schena, G.; Mastrodonato, M.; Gerbino, A.; Bagnoli, P.; Svelto, M. Beta3 adrenergic receptor in the kidney may be a new player in sympathetic regulation of renal function. Kidney Int. 2016, 90, 555-567. [CrossRef]

4. Decara, J.; Rivera, P.; Arrabal, S.; Vargas, A.; Serrano, A.; Pavon, F.J.; Dieguez, C.; Nogueiras, R.; Rodriguez de Fonseca, F.; Suarez, J. Cooperative role of the glucagon-like peptide-1 receptor and $\beta 3$-adrenergic-mediated signalling on fat mass reduction through the downregulation of pka/akt/ampk signalling in the adipose tissue and muscle of rats. Acta Physiol. 2018, 222, e13008. [CrossRef]

5. Banfi, S.; Gusarova, V.; Gromada, J.; Cohen, J.C.; Hobbs, H.H. Increased thermogenesis by a noncanonical pathway in angptl3/8-deficient mice. Proc. Natl. Acad. Sci. USA 2018, 115, E1249-E1258. [CrossRef] [PubMed]

6. Zhang, X.; Hartung, J.E.; Bortsov, A.V.; Kim, S.; O’Buckley, S.C.; Kozlowski, J.; Nackley, A.G. Sustained stimulation of $\beta 2$ - and $\beta 3$-adrenergic receptors leads to persistent functional pain and neuroinflammation. Brain Behav. Immun. 2018, 73, 520-532. [CrossRef] [PubMed]

7. Chapple, C.R.; Cardozo, L.; Nitti, V.W.; Siddiqui, E.; Michel, M.C. Mirabegron in overactive bladder: A review of efficacy, safety, and tolerability. Neurourol. Urodyn. 2014, 33, 17-30. [CrossRef] [PubMed]

8. Balligand, J.L. Cardiac $\beta 3$-adrenergic receptors in the clinical arena: The end of the beginning. Eur. J. Heart Fail. 2017, 19, 576-578. [CrossRef] 
9. Baskin, A.S.; Linderman, J.D.; Brychta, R.J.; McGehee, S.; Anflick-Chames, E.; Cero, C.; Johnson, J.W.; O'Mara, A.E.; Fletcher, L.A.; Leitner, B.P.; et al. Regulation of human adipose tissue activation, gallbladder size, and bile acid metabolism by a $\beta 3$-adrenergic receptor agonist. Diabetes 2018, 67, 2113-2125. [CrossRef]

10. Jesus, I.C.; Alle, L.F.; Munhoz, E.C.; Silva, L.R.D.; Lopes, W.A.; Tureck, L.V.; Purim, K.S.M.; Titski, A.C.K.; Leite, N. Trp64Arg polymorphism of the ADRB3 gene associated with maximal fat oxidation and LDL-C levels in non-obese adolescents. J. Pediatr. 2018, 94, 425-431. [CrossRef]

11. Sakane, N.; Sato, J.; Tsushita, K.; Tsujii, S.; Kotani, K.; Tominaga, M.; Kawazu, S.; Sato, Y.; Usui, T.; Kamae, I.; et al. Effects of lifestyle intervention on weight and metabolic parameters in patients with impaired glucose tolerance related to $\beta-3$ adrenergic receptor gene polymorphism $\operatorname{Trp} 64 \operatorname{Arg}(\mathrm{C} / \mathrm{T})$ : Results from the japan diabetes prevention program. J. Diabetes Investig. 2016, 7, 338-342. [CrossRef]

12. Granneman, J.G.; Lahners, K.N.; Chaudhry, A. Molecular cloning and expression of the rat $\beta 3$-adrenergic receptor. Mol. Pharmacol. 1991, 40, 895-899.

13. Nahmias, C.; Blin, N.; Elalouf, J.M.; Mattei, M.G.; Strosberg, A.D.; Emorine, L.J. Molecular characterization of the mouse $\beta 3$-adrenergic receptor: Relationship with the atypical receptor of adipocytes. EMBO J. 1991, 10, 3721-3727. [CrossRef] [PubMed]

14. Forrest, R.H.; Hickford, J.G. Rapid communication: Nucleotide sequences of the bovine, caprine, and ovine beta3-adrenergic receptor genes. J. Anim. Sci. 2000, 78, 1397-1398. [CrossRef]

15. Sasaki, N.; Uchida, E.; Niiyama, M.; Yoshida, T.; Saito, M. Anti-obesity effects of selective agonists to the $\beta 3$-adrenergic receptor in dogs. I. The presence of canine $\beta 3$-adrenergic receptor and in vivo lipomobilization by its agonists. J. Vet. Med. Sci. 1998, 60, 459-463. [CrossRef]

16. Jockers, R.; Da Silva, A.; Strosberg, A.D.; Bouvier, M.; Marullo, S. New molecular and structural determinants involved in $\beta 2$-adrenergic receptor desensitization and sequestration. Delineation using chimeric $\beta 3 / \beta 2$-adrenergic receptors. J. Biol. Chem. 1996, 271, 9355-9362. [CrossRef] [PubMed]

17. Nantel, F.; Bonin, H.; Emorine, L.J.; Zilberfarb, V.; Strosberg, A.D.; Bouvier, M.; Marullo, S. The human $\beta 3$-adrenergic receptor is resistant to short term agonist-promoted desensitization. Mol. Pharmacol. 1993, 43, 548-555.

18. Granneman, J.G.; Lahners, K.N.; Chaudhry, A. Characterization of the human $\beta 3$-adrenergic receptor gene. Mol. Pharmacol. 1993, 44, 264-270. [PubMed]

19. Van Spronsen, A.; Nahmias, C.; Krief, S.; Briend-Sutren, M.M.; Strosberg, A.D.; Emorine, L.J. The promoter and intron/exon structure of the human and mouse $\beta 3$-adrenergic-receptor genes. Eur. J. Biochem. 1993, 213, 1117-1124. [CrossRef] [PubMed]

20. Evans, B.A.; Papaioannou, M.; Hamilton, S.; Summers, R.J. Alternative splicing generates two isoforms of the B3-adrenoceptor which are differentially expressed in mouse tissues. Br. J. Pharmacol. 1999, 127, 1525-1531. [CrossRef]

21. Hutchinson, D.S.; Bengtsson, T.; Evans, B.A.; Summers, R.J. Mouse $\beta 3 a-$ and $\beta 3$ b-adrenoceptors expressed in chinese hamster ovary cells display identical pharmacology but utilize distinct signalling pathways. Br. J. Pharmacol. 2002, 135, 1903-1914. [CrossRef] [PubMed]

22. Milano, S.; Gerbino, A.; Schena, G.; Carmosino, M.; Svelto, M.; Procino, G. Human $\beta 3$-adrenoreceptor is resistant to agonist-induced desensitization in renal epithelial cells. Cell Physiol. Biochem. 2018, 48, 847-862. [CrossRef] [PubMed]

23. Okeke, K.; Angers, S.; Bouvier, M.; Michel, M.C. Agonist-induced desensitisation of $\beta 3$-adrenoceptors: Where, when and how? Br. J. Pharmacol. 2019. [CrossRef] [PubMed]

24. Lefkowitz, R.J. G protein-coupled receptors. III. New roles for receptor kinases and $\beta$-arrestins in receptor signaling and desensitization. J. Biol. Chem. 1998, 273, 18677-18680. [CrossRef] [PubMed]

25. Michel-Reher, M.B.; Michel, M.C. Agonist-induced desensitization of human $\beta 3$-adrenoceptors expressed in human embryonic kidney cells. Naunyn Schmiedebergs Arch. Pharmacol. 2013, 386, 843-851. [CrossRef]

26. Strosberg, A.D.; Pietri-Rouxel, F. Function and regulation of the $\beta 3$-adrenoceptor. Trends Pharmacol. Sci. 1996, 17, 373-381. [CrossRef]

27. Moffett, S.; Mouillac, B.; Bonin, H.; Bouvier, M. Altered phosphorylation and desensitization patterns of a human $\beta 2$-adrenergic receptor lacking the palmitoylated Cys341. EMBO J. 1993, 12, 349-356. [CrossRef]

28. Baker, J.G. The selectivity of beta-adrenoceptor antagonists at the human $\beta 1, \beta 2$ and $\beta 3$ adrenoceptors. Br. J. Pharmacol. 2005, 144, 317-322. [CrossRef]

29. Dessy, C.; Balligand, J.L. Beta3-adrenergic receptors in cardiac and vascular tissues emerging concepts and therapeutic perspectives. Adv. Pharmacol. 2010, 59, 135-163. 
30. Emorine, L.; Blin, N.; Strosberg, A.D. The human $\beta 3$-adrenoceptor: The search for a physiological function. Trends Pharmacol. Sci. 1994, 15, 3-7. [CrossRef]

31. Hoffmann, C.; Leitz, M.R.; Oberdorf-Maass, S.; Lohse, M.J.; Klotz, K.N. Comparative pharmacology of human beta-adrenergic receptor subtypes-Characterization of stably transfected receptors in cho cells. Naunyn Schmiedebergs Arch. Pharmacol. 2004, 369, 151-159. [CrossRef]

32. Rozec, B.; Gauthier, C. Beta3-adrenoceptors in the cardiovascular system: Putative roles in human pathologies. Pharmacol. Ther. 2006, 111, 652-673. [CrossRef]

33. Strosberg, A.D. Structure and function of the $\beta 3$-adrenergic receptor. Annu. Rev. Pharmacol. Toxicol. 1997, 37, 421-450. [CrossRef]

34. Perrone, M.G.; Bleve, L.; Santandrea, E.; Vitale, P.; Niso, M.; Scilimati, A. The tertiary amine nitrogen atom of piperazine sulfonamides as a novel determinant of potent and selective $\beta 3$-adrenoceptor agonists. ChemMedChem 2009, 4, 2080-2097. [CrossRef]

35. Perrone, M.G.; Scilimati, A. B3-adrenoceptor agonists and (antagonists as) inverse agonists: History, perspective, constitutive activity, and stereospecific binding. Methods Enzymol. 2010, 484, 197-230.

36. Cernecka, H.; Sand, C.; Michel, M.C. The odd sibling: Features of $\beta 3$-adrenoceptor pharmacology. Mol. Pharmacol. 2014, 86, 479-484. [CrossRef]

37. Vrydag, W.; Michel, M.C. Tools to study ß3-adrenoceptors. Naunyn Schmiedebergs Arch. Pharmacol. 2007, 374, $385-398$. [CrossRef]

38. Takasu, T.; Ukai, M.; Sato, S.; Matsui, T.; Nagase, I.; Maruyama, T.; Sasamata, M.; Miyata, K.; Uchida, H.; Yamaguchi, O. Effect of (r)-2-(2-aminothiazol-4-yl)-4'-\{2-[(2-hydroxy-2-phenylethyl)amino]ethyl $\}$ acetanilide (ym178), a novel selective beta3-adrenoceptor agonist, on bladder function. J. Pharmacol. Exp. Ther. 2007, 321, 642-647. [CrossRef]

39. Bianchetti, A.; Manara, L. In vitro inhibition of intestinal motility by phenylethanolaminotetralines: Evidence of atypical beta-adrenoceptors in rat colon. Br. J. Pharmacol. 1990, 100, 831-839. [CrossRef]

40. Sanofi. Available online: http://www.sanofi.com/ (accessed on 14 February 2019).

41. Simiand, J.; Keane, P.E.; Guitard, J.; Langlois, X.; Gonalons, N.; Martin, P.; Bianchetti, A.; Le Fur, G.; Soubrie, P. Antidepressant profile in rodents of sr 58611a, a new selective agonist for atypical beta-adrenoceptors. Eur. J. Pharmacol. 1992, 219, 193-201. [CrossRef]

42. Hicks, A.; McCafferty, G.P.; Riedel, E.; Aiyar, N.; Pullen, M.; Evans, C.; Luce, T.D.; Coatney, R.W.; Rivera, G.C.; Westfall, T.D.; et al. Gw427353 (solabegron), a novel, selective beta3-adrenergic receptor agonist, evokes bladder relaxation and increases micturition reflex threshold in the dog. J. Pharmacol. Exp. Ther. 2007, 323, 202-209. [CrossRef] [PubMed]

43. Ohlstein, E.H.; von Keitz, A.; Michel, M.C. A multicenter, double-blind, randomized, placebo-controlled trial of the ß3-adrenoceptor agonist solabegron for overactive bladder. Eur. Urol. 2012, 62, 834-840. [CrossRef] [PubMed]

44. Igawa, Y.; Schneider, T.; Yamazaki, Y.; Tatemichi, S.; Homma, Y.; Nishizawa, O.; Michel, M.C. Functional investigation of beta-adrenoceptors in human isolated detrusor focusing on the novel selective 33-adrenoceptor agonist kuc-7322. Naunyn Schmiedebergs Arch. Pharmacol. 2012, 385, 759-767. [CrossRef] [PubMed]

45. Michel, M.C.; Korstanje, C. Beta3-adrenoceptor agonists for overactive bladder syndrome: Role of translational pharmacology in a repositioning clinical drug development project. Pharmacol. Ther. 2016, 159, 66-82. [CrossRef]

46. Keam, S.J. Vibegron: First global approval. Drugs 2018, 78, 1835-1839. [CrossRef] [PubMed]

47. Yoshida, M.; Takeda, M.; Gotoh, M.; Nagai, S.; Kurose, T. Vibegron, a novel potent and selective $\beta 3$-adrenoreceptor agonist, for the treatment of patients with overactive bladder: A randomized, double-blind, placebo-controlled phase 3 study. Eur. Urol. 2018, 73, 783-790. [CrossRef] [PubMed]

48. Blin, N.; Nahmias, C.; Drumare, M.F.; Strosberg, A.D. Mediation of most atypical effects by species homologues of the beta 3-adrenoceptor. Br. J. Pharmacol. 1994, 112, 911-919. [CrossRef]

49. D'Agostino, G.; Condino, A.M.; Calvi, P. Involvement of $\beta 3$-adrenoceptors in the inhibitory control of cholinergic activity in human bladder: Direct evidence by [(3)h]-acetylcholine release experiments in the isolated detrusor. Eur. J. Pharmacol. 2015, 758, 115-122. [CrossRef] [PubMed]

50. Mitidieri, E.; Tramontano, T.; Gurgone, D.; Imbimbo, C.; Mirone, V.; Fusco, F.; Cirino, G.; d'Emmanuele di Villa Bianca, R.; Sorrentino, R. Beta3 adrenergic receptor activation relaxes human corpus cavernosum and penile artery through a hydrogen sulfide/cgmp-dependent mechanism. Pharmacol. Res. 2017, 124, 100-104. [CrossRef] 
51. Baker, J.G. The selectivity of $\beta$-adrenoceptor agonists at human $\beta 1$-, $\beta 2$ - and $\beta 3$-adrenoceptors. Br. J. Pharmacol. 2010, 160, 1048-1061. [CrossRef]

52. Leblais, V.; Pourageaud, F.; Ivorra, M.D.; Marthan, R.; Muller, B. Comparison of the alpha-adrenoceptor-mediated effects of $\beta 3$-adrenoceptor ligands in rat pulmonary artery. Naunyn Schmiedebergs Arch. Pharmacol. 2005, 371, 535-539. [CrossRef]

53. Pott, C.; Brixius, K.; Bundkirchen, A.; Bolck, B.; Bloch, W.; Steinritz, D.; Mehlhorn, U.; Schwinger, R.H. The preferential $\beta 3$-adrenoceptor agonist brl 37344 increases force via $\beta 1-/ \beta 2$-adrenoceptors and induces endothelial nitric oxide synthase via beta3-adrenoceptors in human atrial myocardium. Br. J. Pharmacol. 2003, 138, 521-529. [CrossRef]

54. Wuest, M.; Eichhorn, B.; Grimm, M.O.; Wirth, M.P.; Ravens, U.; Kaumann, A.J. Catecholamines relax detrusor through $\beta 2$-adrenoceptors in mouse and $\beta 3$-adrenoceptors in man. J. Pharmacol. Exp. Ther. 2009, 328, $213-222$. [CrossRef]

55. Hutchinson, D.S.; Chernogubova, E.; Sato, M.; Summers, R.J.; Bengtsson, T. Agonist effects of zinterol at the mouse and human $\beta 3$-adrenoceptor. Naunyn Schmiedebergs Arch. Pharmacol. 2006, 373, 158-168. [CrossRef] [PubMed]

56. Puzzo, D.; Raiteri, R.; Castaldo, C.; Capasso, R.; Pagano, E.; Tedesco, M.; Gulisano, W.; Drozd, L.; Lippiello, P.; Palmeri, A.; et al. Cl316,243, a $\beta 3$-adrenergic receptor agonist, induces muscle hypertrophy and increased strength. Sci. Rep. 2016, 5, 37504. [CrossRef] [PubMed]

57. Lynch, G.S.; Ryall, J.G. Role of beta-adrenoceptor signaling in skeletal muscle: Implications for muscle wasting and disease. Physiol. Rev. 2008, 88, 729-767. [CrossRef]

58. Karimi Galougahi, K.; Liu, C.C.; Garcia, A.; Gentile, C.; Fry, N.A.; Hamilton, E.J.; Hawkins, C.L.; Figtree, G.A. B3 adrenergic stimulation restores nitric oxide/redox balance and enhances endothelial function in hyperglycemia. J. Am. Heart Assoc. 2016, 5, e002824. [CrossRef]

59. Biers, S.M.; Reynard, J.M.; Brading, A.F. The effects of a new selective $\beta 3$-adrenoceptor agonist (GW427353) on spontaneous activity and detrusor relaxation in human bladder. BJU Int. 2006, 98, 1310-1314. [CrossRef]

60. Rodriguez, M.; Carillon, C.; Coquerel, A.; Le Fur, G.; Ferrara, P.; Caput, D.; Shire, D. Evidence for the presence of $\beta 3$-adrenergic receptor mrna in the human brain. Brain Res. Mol. Brain Res. 1995, 29, 369-375. [CrossRef]

61. Summers, R.J.; Papaioannou, M.; Harris, S.; Evans, B.A. Expression of $\beta 3$-adrenoceptor mrna in rat brain. Br. J. Pharmacol. 1995, 116, 2547-2548. [CrossRef] [PubMed]

62. Consoli, D.; Leggio, G.M.; Mazzola, C.; Micale, V.; Drago, F. Behavioral effects of the $\beta 3$ adrenoceptor agonist sr58611a: Is it the putative prototype of a new class of antidepressant/anxiolytic drugs? Eur. J. Pharmacol. 2007, 573, 139-147. [CrossRef]

63. Overstreet, D.H.; Stemmelin, J.; Griebel, G. Confirmation of antidepressant potential of the selective $\beta 3$ adrenoceptor agonist amibegron in an animal model of depression. Pharmacol. Biochem. Behav. 2008, 89, 623-626. [CrossRef]

64. Stemmelin, J.; Cohen, C.; Terranova, J.P.; Lopez-Grancha, M.; Pichat, P.; Bergis, O.; Decobert, M.; Santucci, V.; Francon, D.; Alonso, R.; et al. Stimulation of the $\beta 3$-adrenoceptor as a novel treatment strategy for anxiety and depressive disorders. Neuropsychopharmacology 2008, 33, 574-587. [CrossRef]

65. Stemmelin, J.; Cohen, C.; Yalcin, I.; Keane, P.; Griebel, G. Implication of $\beta 3$-adrenoceptors in the antidepressant-like effects of amibegron using adrb3 knockout mice in the chronic mild stress. Behav. Brain Res. 2010, 206, 310-312. [CrossRef]

66. Jin, J.; Miao, C.; Wang, Z.; Zhang, W.; Zhang, X.; Xie, X.; Lu, W. Design and synthesis of aryloxypropanolamine as $\beta 3$-adrenergic receptor antagonist in cancer and lipolysis. Eur. J. Med. Chem. 2018, 150, 757-770. [CrossRef]

67. Wada, Y.; Nakano, S.; Morimoto, A.; Kasahara, K.I.; Hayashi, T.; Takada, Y.; Suzuki, H.; Niwa-Sakai, M.; Ohashi, S.; Mori, M.; et al. Discovery of novel indazole derivatives as orally available $\beta 3$-adrenergic receptor agonists lacking off-target-based cardiovascular side effects. J. Med. Chem. 2017, 60, 3252-3265. [CrossRef]

68. Tewatia, P.; Malik, B.K.; Sahi, S. Identification of novel $\beta 3$-adrenoceptor agonists using energetic analysis, structure based pharmacophores and virtual screening. Comb. Chem. High. Throughput Screen 2012, 15, 623-640. [CrossRef]

69. Manara, L.; Croci, T.; Landi, M. ß3-adrenoceptors and intestinal motility. Fundam. Clin. Pharmacol. 1995, 9, $332-342$. [CrossRef]

70. Nisoli, E.; Tonello, C.; Landi, M.; Carruba, M.O. Functional studies of the first selective $\beta 3$-adrenergic receptor antagonist sr 59230a in rat brown adipocytes. Mol. Pharmacol. 1996, 49, 7-14. 
71. Casini, G.; Dal Monte, M.; Fornaciari, I.; Filippi, L.; Bagnoli, P. The $\beta$-adrenergic system as a possible new target for pharmacologic treatment of neovascular retinal diseases. Prog. Retin Eye Res. 2014, 42, 103-129. [CrossRef]

72. Wang, B.; Xu, M.; Li, W.; Li, X.; Zheng, Q.; Niu, X. Aerobic exercise protects against pressure overload-induced cardiac dysfunction and hypertrophy via ß3-AR-nNOS-NO activation. PLoS ONE 2017, 12, e0179648. [CrossRef]

73. Wu, M.J.; Shin, D.H.; Kim, M.Y.; Park, C.G.; Kim, Y.D.; Lee, J.; Park, I.K.; Choi, S.; So, I.; Park, J.S.; et al. Functional effects of $\beta 3$-adrenoceptor on pacemaker activity in interstitial cells of cajal from the mouse colon. Eur. J. Pharmacol. 2015, 754, 32-40. [CrossRef] [PubMed]

74. Niclauss, N.; Michel-Reher, M.B.; Alewijnse, A.E.; Michel, M.C. Comparison of three radioligands for the labelling of human $\beta$-adrenoceptor subtypes. Naunyn Schmiedebergs Arch. Pharmacol. 2006, 374, 99-105. [CrossRef] [PubMed]

75. Sato, M.; Horinouchi, T.; Hutchinson, D.S.; Evans, B.A.; Summers, R.J. Ligand-directed signaling at the $\beta 3$-adrenoceptor produced by 3-(2-ethylphenoxy)-1-[(1,s)-1,2,3,4-tetrahydronapth-1-ylamino]-2s-2-propanol oxalate (sr59230a) relative to receptor agonists. Mol. Pharmacol. 2007, 72, 1359-1368. [CrossRef]

76. Hutchinson, D.S.; Sato, M.; Evans, B.A.; Christopoulos, A.; Summers, R.J. Evidence for pleiotropic signaling at the mouse $\beta 3$-adrenoceptor revealed by sr59230a [3-(2-ethylphenoxy)-1-[(1,s)-1,2,3,4-tetrahydronapth1-ylamino]-2s-2-propanol oxalate]. J. Pharmacol. Exp. Ther. 2005, 312, 1064-1074. [CrossRef] [PubMed]

77. Candelore, M.R.; Deng, L.; Tota, L.; Guan, X.M.; Amend, A.; Liu, Y.; Newbold, R.; Cascieri, M.A.; Weber, A.E. Potent and selective human $\beta 3$-adrenergic receptor antagonists. J. Pharmacol. Exp. Ther. 1999, 290, 649-655.

78. Van Wieringen, J.P.; Michel-Reher, M.B.; Hatanaka, T.; Ueshima, K.; Michel, M.C. The new radioligand [(3)h]-1 748,337 differentially labels human and rat $\beta 3$-adrenoceptors. Eur. J. Pharmacol. 2013, 720, 124-130. [CrossRef] [PubMed]

79. Sato, M.; Hutchinson, D.S.; Evans, B.A.; Summers, R.J. The $\beta 3$-adrenoceptor agonist 4-[[(Hexylamino) carbonyl] amino]-N-[4-[2-[[(2S)-2-hydroxy-3-(4-hydroxyphenoxy) propyl] amino] ethyl]-phenyl]-benzenesulfonamide (L755507) and antagonist (S)- $\mathrm{N}$-[4-[2-[[3-[3-(acetamidomethyl) phenoxy]-2-hydroxypropyl] amino]-ethyl] phenyl] benzenesulfonamide (L748337) activate different signaling pathways in Chinese hamster ovary-K1 cells stably expressing the human $\beta 3$-adrenoceptor. Mol. Pharmacol. 2008, 74, 1417-1428. [PubMed]

80. Uhlen, M.; Fagerberg, L.; Hallstrom, B.M.; Lindskog, C.; Oksvold, P.; Mardinoglu, A.; Sivertsson, A.; Kampf, C.; Sjostedt, E.; Asplund, A.; et al. Proteomics. Tissue-based map of the human proteome. Science 2015, 347, 1260419. [CrossRef] [PubMed]

81. Michel, M.C.; Vrydag, W. $\alpha 1-, \alpha 2$ - and $\beta$-adrenoceptors in the urinary bladder, urethra and prostate. Br. J. Pharmacol. 2006, 147 (Suppl. 2), S88-S119. [CrossRef]

82. Shen, H.; Chen, Z.; Mokhtar, A.D.; Bi, X.; Wu, G.; Gong, S.; Huang, C.; Li, S.; Du, S. Expression of beta-adrenergic receptor subtypes in human normal and dilated ureter. Int. Urol. Nephrol. 2017, 49, 1771-1778. [CrossRef] [PubMed]

83. Limberg, B.J.; Andersson, K.E.; Aura Kullmann, F.; Burmer, G.; de Groat, W.C.; Rosenbaum, J.S. $\beta$-adrenergic receptor subtype expression in myocyte and non-myocyte cells in human female bladder. Cell Tissue Res. 2010, 342, 295-306. [CrossRef] [PubMed]

84. Calmasini, F.B.; Candido, T.Z.; Alexandre, E.C.; D’Ancona, C.A.; Silva, D.; de Oliveira, M.A.; De Nucci, G.; Antunes, E.; Monica, F.Z. The $\beta-3$ adrenoceptor agonist, mirabegron relaxes isolated prostate from human and rabbit: New therapeutic indication? Prostate 2015, 75, 440-447. [CrossRef] [PubMed]

85. Otsuka, A.; Shinbo, H.; Matsumoto, R.; Kurita, Y.; Ozono, S. Expression and functional role of $\beta$-adrenoceptors in the human urinary bladder urothelium. Naunyn Schmiedebergs Arch. Pharmacol. 2008, 377, 473-481. [CrossRef] [PubMed]

86. Yamaguchi, O. $\beta 3$-adrenoceptors in human detrusor muscle. Urology 2002, 59, 25-29. [CrossRef]

87. Larsen, J.J. Alpha and beta-adrenoceptors in the detrusor muscle and bladder base of the pig and $\beta$-adrenoceptors in the detrusor muscle of man. Br. J. Pharmacol. 1979, 65, 215-222. [CrossRef]

88. Igawa, Y.; Yamazaki, Y.; Takeda, H.; Hayakawa, K.; Akahane, M.; Ajisawa, Y.; Yoneyama, T.; Nishizawa, O.; Andersson, K.E. Functional and molecular biological evidence for a possible $\beta 3$-adrenoceptor in the human detrusor muscle. Br. J. Pharmacol. 1999, 126, 819-825. [CrossRef] [PubMed]

89. Peirce, V.; Carobbio, S.; Vidal-Puig, A. The different shades of fat. Nature 2014, 510, 76-83. [CrossRef] 
90. Tagaya, E.; Tamaoki, J.; Takemura, H.; Isono, K.; Nagai, A. Atypical adrenoceptor-mediated relaxation of canine pulmonary artery through a cyclic adenosine monophosphate-dependent pathway. Lung 1999, 177, 321-332. [CrossRef]

91. Tanaka, Y.; Horinouchi, T.; Koike, K. New insights into beta-adrenoceptors in smooth muscle: Distribution of receptor subtypes and molecular mechanisms triggering muscle relaxation. Clin. Exp. Pharmacol. Physiol. 2005, 32, 503-514. [CrossRef]

92. Uchida, H.; Shishido, K.; Nomiya, M.; Yamaguchi, O. Involvement of cyclic amp-dependent and -independent mechanisms in the relaxation of rat detrusor muscle via $\beta$-adrenoceptors. Eur. J. Pharmacol. 2005, 518, 195-202. [CrossRef]

93. Maki, T.; Kajioka, S.; Itsumi, M.; Kareman, E.; Lee, K.; Shiota, M.; Eto, M. Mirabegron induces relaxant effects via camp signaling-dependent and -independent pathways in detrusor smooth muscle. Low. Urin. Tract Symptoms 2019. [CrossRef]

94. Frazier, E.P.; Mathy, M.J.; Peters, S.L.; Michel, M.C. Does cyclic amp mediate rat urinary bladder relaxation by isoproterenol? J. Pharmacol. Exp. Ther. 2005, 313, 260-267. [CrossRef]

95. Patel, H.J.; Giembycz, M.A.; Keeling, J.E.; Barnes, P.J.; Belvisi, M.G. Inhibition of cholinergic neurotransmission in guinea pig trachea by ns1619, a putative activator of large-conductance, calcium-activated potassium channels. J. Pharmacol. Exp. Ther. 1998, 286, 952-958.

96. Coelho, A.; Antunes-Lopes, T.; Gillespie, J.; Cruz, F. $\beta-3$ adrenergic receptor is expressed in acetylcholine-containing nerve fibers of the human urinary bladder: An immunohistochemical study. Neurourol. Urodyn. 2017, 36, 1972-1980. [CrossRef]

97. Kaufmann, J.; Martinka, P.; Moede, O.; Sendeski, M.; Steege, A.; Fahling, M.; Hultstrom, M.; Gaestel, M.; Moraes-Silva, I.C.; Nikitina, T.; et al. Noradrenaline enhances angiotensin ii responses via p38 mapk activation after hypoxia/re-oxygenation in renal interlobar arteries. Acta Physiol. 2015, 213, 920-932. [CrossRef]

98. Rojek, A.; Nielsen, J.; Brooks, H.L.; Gong, H.; Kim, Y.H.; Kwon, T.H.; Frokiaer, J.; Nielsen, S. Altered expression of selected genes in kidney of rats with lithium-induced ndi. Am. J. Physiol. Renal. Physiol. 2005, 288, F1276-F1289. [CrossRef] [PubMed]

99. Rains, S.L.; Amaya, C.N.; Bryan, B.A. $\beta$-adrenergic receptors are expressed across diverse cancers. Oncoscience 2017, 4, 95-105.

100. Chen, S.F.; Lee, C.L.; Kuo, H.C. Changes in sensory proteins in the bladder urothelium of patients with chronic kidney disease and end-stage renal disease. Low. Urin. Tract Symptoms 2018. [CrossRef]

101. Michel, M.C.; Gravas, S. Safety and tolerability of $\beta 3$-adrenoceptor agonists in the treatment of overactive bladder syndrome-insig.ht from transcriptosome and experimental studies. Expert Opin Drug Saf. 2016, 15, 647-657.

102. Arch, J.R.; Ainsworth, A.T.; Cawthorne, M.A.; Piercy, V.; Sennitt, M.V.; Thody, V.E.; Wilson, C.; Wilson, S. Atypical $\beta$-adrenoceptor on brown adipocytes as target for anti-obesity drugs. Nature 1984, 309, 163-165. [CrossRef] [PubMed]

103. Krief, S.; Lonnqvist, F.; Raimbault, S.; Baude, B.; Van Spronsen, A.; Arner, P.; Strosberg, A.D.; Ricquier, D.; Emorine, L.J. Tissue distribution of $\beta 3$-adrenergic receptor mrna in man. J. Clin. Investig. 1993, 91, 344-349. [CrossRef]

104. Chamberlain, P.D.; Jennings, K.H.; Paul, F.; Cordell, J.; Berry, A.; Holmes, S.D.; Park, J.; Chambers, J.; Sennitt, M.V.; Stock, M.J.; et al. The tissue distribution of the human $\beta 3$-adrenoceptor studied using a monoclonal antibody: Direct evidence of the $\beta 3$-adrenoceptor in human adipose tissue, atrium and skeletal muscle. Int. J. Obes. Relat. Metab. Disord 1999, 23, 1057-1065. [CrossRef] [PubMed]

105. De Matteis, R.; Arch, J.R.; Petroni, M.L.; Ferrari, D.; Cinti, S.; Stock, M.J. Immunohistochemical identification of the $\beta 3$-adrenoceptor in intact human adipocytes and ventricular myocardium: Effect of obesity and treatment with ephedrine and caffeine. Int. J. Obes. Relat. Metab. Disord 2002, 26, 1442-1450. [CrossRef]

106. Cypess, A.M.; Lehman, S.; Williams, G.; Tal, I.; Rodman, D.; Goldfine, A.B.; Kuo, F.C.; Palmer, E.L.; Tseng, Y.H.; Doria, A.; et al. Identification and importance of brown adipose tissue in adult humans. N. Engl. J. Med. 2009, 360, 1509-1517. [CrossRef]

107. Hibi, M.; Oishi, S.; Matsushita, M.; Yoneshiro, T.; Yamaguchi, T.; Usui, C.; Yasunaga, K.; Katsuragi, Y.; Kubota, K.; Tanaka, S.; et al. Brown adipose tissue is involved in diet-induced thermogenesis and whole-body fat utilization in healthy humans. Int. J. Obes. 2016, 40, 1655-1661. [CrossRef]

108. Sennitt, M.V.; Kaumann, A.J.; Molenaar, P.; Beeley, L.J.; Young, P.W.; Kelly, J.; Chapman, H.; Henson, S.M.; Berge, J.M.; Dean, D.K.; et al. The contribution of classical ( $\beta 1 / 2-)$ and atypical beta-adrenoceptors to 
the stimulation of human white adipocyte lipolysis and right atrial appendage contraction by novel ß3-adrenoceptor agonists of differing selectivities. J. Pharmacol. Exp. Ther. 1998, 285, 1084-1095.

109. Tavernier, G.; Barbe, P.; Galitzky, J.; Berlan, M.; Caput, D.; Lafontan, M.; Langin, D. Expression of $\beta 3$-adrenoceptors with low lipolytic action in human subcutaneous white adipocytes. J. Lipid Res. 1996, 37, 87-97.

110. Robidoux, J.; Kumar, N.; Daniel, K.W.; Moukdar, F.; Cyr, M.; Medvedev, A.V.; Collins, S. Maximal $\beta 3$-adrenergic regulation of lipolysis involves src and epidermal growth factor receptor-dependent ERK1/2 activation. J. Biol. Chem. 2006, 281, 37794-37802. [CrossRef]

111. Soeder, K.J.; Snedden, S.K.; Cao, W.; Della Rocca, G.J.; Daniel, K.W.; Luttrell, L.M.; Collins, S. The $\beta 3$-adrenergic receptor activates mitogen-activated protein kinase in adipocytes through a Gi-dependent mechanism. J. Biol. Chem. 1999, 274, 12017-12022. [CrossRef]

112. Hodis, J.; Vaclavikova, R.; Farghali, H. $\beta-3$ agonist-induced lipolysis and nitric oxide production: Relationship to ppargamma agonist/antagonist and amp kinase modulation. Gen. Physiol. Biophys. 2011, 30, 90-99. [CrossRef]

113. Barbatelli, G.; Murano, I.; Madsen, L.; Hao, Q.; Jimenez, M.; Kristiansen, K.; Giacobino, J.P.; De Matteis, R.; Cinti, S. The emergence of cold-induced brown adipocytes in mouse white fat depots is determined predominantly by white to brown adipocyte transdifferentiation. Am. J. Physiol. Endocrinol. Metab. 2010, 298, E1244-E1253. [CrossRef]

114. Jiang, Y.; Berry, D.C.; Graff, J.M. Distinct cellular and molecular mechanisms for $\beta 3$ adrenergic receptor-induced beige adipocyte formation. Elife 2017, 6, e30329. [CrossRef]

115. De Jong, J.M.A.; Wouters, R.T.F.; Boulet, N.; Cannon, B.; Nedergaard, J.; Petrovic, N. The $\beta 3$-adrenergic receptor is dispensable for browning of adipose tissues. Am. J. Physiol. Endocrinol. Metab. 2017, 312, E508-E518. [CrossRef]

116. Susulic, V.S.; Frederich, R.C.; Lawitts, J.; Tozzo, E.; Kahn, B.B.; Harper, M.E.; Himms-Hagen, J.; Flier, J.S.; Lowell, B.B. Targeted disruption of the ß3-adrenergic receptor gene. J. Biol. Chem. 1995, 270, 29483-29492. [CrossRef]

117. Mattsson, C.L.; Csikasz, R.I.; Chernogubova, E.; Yamamoto, D.L.; Hogberg, H.T.; Amri, E.Z.; Hutchinson, D.S.; Bengtsson, T. $\beta 1$-Adrenergic receptors increase UCP1 in human MADS brown adipocytes and rescue cold-acclimated $\beta 3$-adrenergic receptor-knockout mice via nonshivering thermogenesis. Am. J. Physiol. Endocrinol. Metab. 2011, 301, E1108-E1118. [CrossRef]

118. Preite, N.Z.; Nascimento, B.P.; Muller, C.R.; Americo, A.L.; Higa, T.S.; Evangelista, F.S.; Lancellotti, C.L.; Henriques, F.S.; Batista, M.L., Jr.; Bianco, A.C.; et al. Disruption of $\beta 3$ adrenergic receptor increases susceptibility to dio in mouse. J. Endocrinol. 2016, 231, 259-269. [CrossRef]

119. Hong, S.; Song, W.; Zushin, P.H.; Liu, B.; Jedrychowski, M.P.; Mina, A.I.; Deng, Z.; Cabarkapa, D.; Hall, J.A.; Palmer, C.J.; et al. Phosphorylation of $\beta-3$ adrenergic receptor at serine 247 by erk map kinase drives lipolysis in obese adipocytes. Mol. Metab. 2018, 12, 25-38. [CrossRef]

120. Clookey, S.L.; Welly, R.J.; Shay, D.; Woodford, M.L.; Fritsche, K.L.; Rector, R.S.; Padilla, J.; Lubahn, D.B.; Vieira-Potter, V.J. $\beta 3$ adrenergic receptor activation rescues metabolic dysfunction in female estrogen receptor alpha-null mice. Front. Physiol. 2019, 10, 9. [CrossRef]

121. Xiao, C.; Goldgof, M.; Gavrilova, O.; Reitman, M.L. Anti-obesity and metabolic efficacy of the $\beta 3$-adrenergic agonist, CL316243, in mice at thermoneutrality compared to $22{ }^{\circ} \mathrm{C}$. Obesity 2015, 23, 1450-1459. [CrossRef]

122. Bhadada, S.V.; Patel, B.M.; Mehta, A.A.; Goyal, R.K. $\beta 3$ receptors: Role in cardiometabolic disorders. Ther. Adv. Endocrinol. Metab. 2011, 2, 65-79. [CrossRef]

123. Oana, F.; Takeda, H.; Matsuzawa, A.; Akahane, S.; Isaji, M.; Akahane, M. Adiponectin receptor 2 expression in liver and insulin resistance in DB/DB mice given a ß3-adrenoceptor agonist. Eur. J. Pharmacol. 2005, 518, 71-76. [CrossRef]

124. Larsen, T.M.; Toubro, S.; van Baak, M.A.; Gottesdiener, K.M.; Larson, P.; Saris, W.H.; Astrup, A. Effect of a 28-d treatment with L-796568, a novel $\beta 3$-adrenergic receptor agonist, on energy expenditure and body composition in obese men. Am. J. Clin. Nutr. 2002, 76, 780-788. [CrossRef]

125. Van Baak, M.A.; Hul, G.B.; Toubro, S.; Astrup, A.; Gottesdiener, K.M.; DeSmet, M.; Saris, W.H. Acute effect of L-796568, a novel $\beta 3$-adrenergic receptor agonist, on energy expenditure in obese men. Clin. Pharmacol. Ther. 2002, 71, 272-279. [CrossRef]

126. Michel, M.C.; Ochodnicky, P.; Summers, R.J. Tissue functions mediated by $\beta 3$-adrenoceptors-findings and challenges. Naunyn Schmiedebergs Arch. Pharmacol. 2010, 382, 103-108. [CrossRef]

127. Arch, J.R. Challenges in $\beta 3$-adrenoceptor agonist drug development. Ther. Adv. Endocrinol. Metab. 2011, 2, 59-64. [CrossRef] 
128. Negreș, S.; Chiriță, C.; Arsene, A.L.; Margină, D.; Moroșan, E.; Zbârcea, C.E. New potential $\beta-3$ adrenergic agonists with $\beta$-phenylethylamine structure, synthesized for the treatment of dyslipidemia and obesity. In Adiposity: Epidemiology and Treatment Modalities; IntechOpen: London, UK, 2017.

129. Gauthier, C.; Tavernier, G.; Charpentier, F.; Langin, D.; Le Marec, H. Functional $\beta 3$-adrenoceptor in the human heart. J. Clin. Investig. 1996, 98, 556-562. [CrossRef]

130. Berkowitz, D.E.; Nardone, N.A.; Smiley, R.M.; Price, D.T.; Kreutter, D.K.; Fremeau, R.T.; Schwinn, D.A. Distribution of $\beta 3$-adrenoceptor mrna in human tissues. Eur. J. Pharmacol. 1995, 289, 223-228. [CrossRef]

131. Gauthier, C.; Tavernier, G.; Trochu, J.N.; Leblais, V.; Laurent, K.; Langin, D.; Escande, D.; Le Marec, H. Interspecies differences in the cardiac negative inotropic effects of $\beta 3$-adrenoceptor agonists. J. Pharmacol. Exp. Ther. 1999, 290, 687-693.

132. Tavernier, G.; Toumaniantz, G.; Erfanian, M.; Heymann, M.F.; Laurent, K.; Langin, D.; Gauthier, C. $\beta 3$-adrenergic stimulation produces a decrease of cardiac contractility ex vivo in mice overexpressing the human $\beta 3$-adrenergic receptor. Cardiovasc. Res. 2003, 59, 288-296. [CrossRef]

133. Gauthier, C.; Leblais, V.; Kobzik, L.; Trochu, J.N.; Khandoudi, N.; Bril, A.; Balligand, J.L.; Le Marec, H. The negative inotropic effect of $\beta 3$-adrenoceptor stimulation is mediated by activation of a nitric oxide synthase pathway in human ventricle. J. Clin. Invest. 1998, 102, 1377-1384. [CrossRef]

134. Han, X.; Kobzik, L.; Balligand, J.L.; Kelly, R.A.; Smith, T.W. Nitric oxide synthase (nos3)-mediated cholinergic modulation of $\mathrm{Ca}^{2+}$ current in adult rabbit atrioventricular nodal cells. Circ. Res. 1996, 78, 998-1008. [CrossRef] [PubMed]

135. Kou, R.; Michel, T. Epinephrine regulation of the endothelial nitric-oxide synthase roles of rac1 and $\beta 3$-adrenergic receptors in endothelial no signaling. J. Biol. Chem. 2007, 282, 32719-32729. [CrossRef] [PubMed]

136. Salie, R.; Alsalhin, A.K.H.; Marais, E.; Lochner, A. Cardioprotective effects of $\beta 3$-adrenergic receptor ( $\beta 3$-ar) pre-, per-, and post-treatment in ischemia-reperfusion. In Cardiovascular Drugs and Therapy; Springer: Berlin, Germany, 2019.

137. Idigo, W.O.; Reilly, S.; Zhang, M.H.; Zhang, Y.H.; Jayaram, R.; Carnicer, R.; Crabtree, M.J.; Balligand, J.L.; Casadei, B. Regulation of endothelial nitric-oxide synthase (NOS) S-glutathionylation by neuronal NOS: Evidence of a functional interaction between myocardial constitutive NOS isoforms. J. Biol. Chem. 2012, 287, 43665-43673. [CrossRef] [PubMed]

138. Watts, V.L.; Sepulveda, F.M.; Cingolani, O.H.; Ho, A.S.; Niu, X.; Kim, R.; Miller, K.L.; Vandegaer, K.; Bedja, D.; Gabrielson, K.L.; et al. Anti-hypertrophic and anti-oxidant effect of $\beta 3$-adrenergic stimulation in myocytes requires differential neuronal nos phosphorylation. J. Mol. Cell Cardiol. 2013, 62, 8-17. [CrossRef] [PubMed]

139. Gauthier, C.; Langin, D.; Balligand, J.L. Beta3-adrenoceptors in the cardiovascular system. Trends Pharmacol. Sci. 2000, 21, 426-431. [CrossRef]

140. Angelone, T.; Filice, E.; Quintieri, A.M.; Imbrogno, S.; Recchia, A.; Pulera, E.; Mannarino, C.; Pellegrino, D.; Cerra, M.C. $\beta 3$-adrenoceptors modulate left ventricular relaxation in the rat heart via the no-cgmp-pkg pathway. Acta Physiol. 2008, 193, 229-239. [CrossRef]

141. Skeberdis, V.A.; Gendviliene, V.; Zablockaite, D.; Treinys, R.; Macianskiene, R.; Bogdelis, A.; Jurevicius, J.; Fischmeister, R. $\beta 3$-adrenergic receptor activation increases human atrial tissue contractility and stimulates the L-type $\mathrm{Ca}^{2+}$ current. J. Clin. Investig. 2008, 118, 3219-3227. [CrossRef]

142. Christ, T.; Molenaar, P.; Klenowski, P.M.; Ravens, U.; Kaumann, A.J. Human atrial $\beta(1 \mathrm{~L})$-adrenoceptor but not $\beta 3$-adrenoceptor activation increases force and $\mathrm{Ca}^{2+}$ current at physiological temperature. Br. J. Pharmacol. 2011, 162, 823-839. [CrossRef] [PubMed]

143. Treinys, R.; Zablockaite, D.; Gendviliene, V.; Jurevicius, J.; Skeberdis, V.A. $\beta 3$-adrenergic regulation of L-type $\mathrm{Ca}^{2+}$ current and force of contraction in human ventricle. J. Membr. Biol. 2014, 247, 309-318. [CrossRef] [PubMed]

144. Arioglu-Inan, E.; Kayki-Mutlu, G.; Michel, M.C. Cardiac ß3-adrenoceptors-A role in human pathophysiology? Br. J. Pharmacol. 2019. [CrossRef]

145. Mo, W.; Michel, M.C.; Lee, X.W.; Kaumann, A.J.; Molenaar, P. The $\beta 3$-adrenoceptor agonist mirabegron increases human atrial force through $\beta 1$-adrenoceptors: An indirect mechanism? Br. J. Pharmacol. 2017, 174, $2706-2715$. [CrossRef] [PubMed]

146. Balligand, J.L. Cardiac salvage by tweaking with $\beta$-3-adrenergic receptors. Cardiovasc. Res. 2016, 111, $128-133$. [CrossRef] 
147. Hermida, N.; Michel, L.; Esfahani, H.; Dubois-Deruy, E.; Hammond, J.; Bouzin, C.; Markl, A.; Colin, H.; Steenbergen, A.V.; De Meester, C.; et al. Cardiac myocyte $\beta 3$-adrenergic receptors prevent myocardial fibrosis by modulating oxidant stress-dependent paracrine signaling. Eur. Heart J. 2018, 39, 888-898. [CrossRef]

148. Dincer, U.D.; Bidasee, K.R.; Guner, S.; Tay, A.; Ozcelikay, A.T.; Altan, V.M. The effect of diabetes on expression of $\beta 1-, \beta 2-$, and $\beta 3$-adrenoreceptors in rat hearts. Diabetes 2001, 50, 455-461. [CrossRef]

149. Moniotte, S.; Kobzik, L.; Feron, O.; Trochu, J.N.; Gauthier, C.; Balligand, J.L. Upregulation of $\beta 3$-adrenoceptors and altered contractile response to inotropic amines in human failing myocardium. Circulation 2001, 103, 1649-1655. [CrossRef] [PubMed]

150. Moniotte, S.; Belge, C.; Sekkali, B.; Massion, P.B.; Rozec, B.; Dessy, C.; Balligand, J.L. Sepsis is associated with an upregulation of functional $\beta 3$ adrenoceptors in the myocardium. Eur. J. Heart Fail. 2007, 9, 1163-1171. [CrossRef]

151. Aragon, J.P.; Condit, M.E.; Bhushan, S.; Predmore, B.L.; Patel, S.S.; Grinsfelder, D.B.; Gundewar, S.; Jha, S.; Calvert, J.W.; Barouch, L.A.; et al. $\beta 3$-adrenoreceptor stimulation ameliorates myocardial ischemia-reperfusion injury via endothelial nitric oxide synthase and neuronal nitric oxide synthase activation. J. Am. Coll. Cardiol. 2011, 58, 2683-2691. [CrossRef]

152. Cannavo, A.; Koch, W.J. Targeting $\beta 3$-adrenergic receptors in the heart: Selective agonism and beta-blockade. J. Cardiovasc. Pharmacol. 2017, 69, 71-78. [PubMed]

153. Belge, C.; Hammond, J.; Dubois-Deruy, E.; Manoury, B.; Hamelet, J.; Beauloye, C.; Markl, A.; Pouleur, A.C.; Bertrand, L.; Esfahani, H.; et al. Enhanced expression of $\beta 3$-adrenoceptors in cardiac myocytes attenuates neurohormone-induced hypertrophic remodeling through nitric oxide synthase. Circulation 2014, 129, 451-462. [CrossRef]

154. Cannavo, A.; Liccardo, D.; Lymperopoulos, A.; Gambino, G.; D’Amico, M.L.; Rengo, F.; Koch, W.J.; Leosco, D.; Ferrara, N.; Rengo, G. Beta adrenergic receptor kinase c-terminal peptide gene-therapy improves $\beta 2$-adrenergic receptor-dependent neoangiogenesis after hindlimb ischemia. J. Pharmacol. Exp. Ther. 2016, 356, 503-513. [CrossRef] [PubMed]

155. Sorrentino, S.A.; Doerries, C.; Manes, C.; Speer, T.; Dessy, C.; Lobysheva, I.; Mohmand, W.; Akbar, R.; Bahlmann, F.; Besler, C.; et al. Nebivolol exerts beneficial effects on endothelial function, early endothelial progenitor cells, myocardial neovascularization, and left ventricular dysfunction early after myocardial infarction beyond conventional $\beta 1$-blockade. J. Am. Coll. Cardiol. 2011, 57, 601-611. [CrossRef] [PubMed]

156. Nisoli, E.; Tonello, C.; Benarese, M.; Carruba, M.O. Rat Frontal Cortex $\beta 1$-Adrenoceptors Are Activated by the $\beta 3$-Adrenoceptor Agonists SR 58611A and SR 58878A but Not by BRL 37344 or ICI 215,001. J. Neurochem. 1995, 65, 1580-1587. [CrossRef] [PubMed]

157. Ressler, K.J.; Nemeroff, C.B. Role of serotonergic and noradrenergic systems in the pathophysiology of depression and anxiety disorders. Depress. Anxiety 2000, 12 (Suppl. 1), 2-19. [CrossRef]

158. Claustre, Y.; Leonetti, M.; Santucci, V.; Bougault, I.; Desvignes, C.; Rouquier, L.; Aubin, N.; Keane, P.; Busch, S.; Chen, Y.; et al. Effects of the $\beta 3$-adrenoceptor (Adrb3) agonist SR58611A (amibegron) on serotonergic and noradrenergic transmission in the rodent: relevance to its antidepressant/anxiolytic-like profile. Neuroscience 2008, 156, 353-364. [CrossRef]

159. Tamburella, A.; Micale, V.; Leggio, G.M.; Drago, F. The $\beta 3$ adrenoceptor agonist, amibegron (SR58611A) counteracts stress-induced behavioral and neurochemical changes. Eur. Neuropsychopharmacol. 2010, 20, 704-713. [CrossRef]

160. Tanyeri, P.; Buyukokuroglu, M.E.; Mutlu, O.; Ulak, G.; Akar, F.Y.; Celikyurt, I.K.; Erden, B.F. Evidence that the anxiolytic-like effects of the $\beta 3$ receptor agonist amibegron involve serotoninergic receptor activity. Pharmacol. Biochem. Behav. 2013, 110, 27-32. [CrossRef]

161. Jhaveri, D.J.; Mackay, E.W.; Hamlin, A.S.; Marathe, S.V.; Nandam, L.S.; Vaidya, V.A.; Bartlett, P.F. Norepinephrine directly activates adult hippocampal precursors via $\beta 3$-adrenergic receptors. J. Neurosci. 2010, 30, 2795-2806. [CrossRef]

162. Church, T.W.; Brown, J.T.; Marrion, N.V. $\beta 3$-adrenergic receptor-dependent modulation of the medium afterhyperpolarization in rat hippocampal ca1 pyramidal neurons. J. Neurophysiol. 2019, 121, 773-784. [CrossRef]

163. Gibbs, M.E.; Hutchinson, D.S.; Summers, R.J. Role of beta-adrenoceptors in memory consolidation: $\beta 3$-adrenoceptors act on glucose uptake and $\beta 2$-adrenoceptors on glycogenolysis. Neuropsychopharmacology 2008, 33, 2384-2397. [CrossRef]

164. Souza-Braga, P.; Lorena, F.B.; Nascimento, B.P.P.; Marcelino, C.P.; Ravache, T.T.; Ricci, E.; Bernardi, M.M.; Ribeiro, M.O. Adrenergic receptor $\beta 3$ is involved in the memory consolidation process in mice. Braz. J. Med. Biol. Res. 2018, 51, e7564. [CrossRef] 
165. Kanno, T.; Yaguchi, T.; Nishizaki, T. Noradrenaline stimulates atp release from drg neurons by targeting $\beta 3$ adrenoceptors as a factor of neuropathic pain. J. Cell Physiol. 2010, 224, 345-351. [CrossRef]

166. Valdes, A.M.; Abhishek, A.; Muir, K.; Zhang, W.; Maciewicz, R.A.; Doherty, M. Association of $\beta$-blocker use with less prevalent joint pain and lower opioid requirement in people with osteoarthritis. Arthritis Care Res. 2017, 69, 1076-1081. [CrossRef]

167. Mori, A.; Miwa, T.; Sakamoto, K.; Nakahara, T.; Ishii, K. Pharmacological evidence for the presence of functional ß3-adrenoceptors in rat retinal blood vessels. Naunyn Schmiedebergs Arch. Pharmacol. 2010, 382, 119-126. [CrossRef]

168. Steinle, J.J.; Booz, G.W.; Meininger, C.J.; Day, J.N.; Granger, H.J. $\beta 3$-adrenergic receptors regulate retinal endothelial cell migration and proliferation. J. Biol. Chem. 2003, 278, 20681-20686. [CrossRef]

169. Steinle, J.J.; Zamora, D.O.; Rosenbaum, J.T.; Granger, H.J. $\beta 3$-adrenergic receptors mediate choroidal endothelial cell invasion, proliferation, and cell elongation. Exp. Eye Res. 2005, 80, 83-91. [CrossRef] [PubMed]

170. Ristori, C.; Filippi, L.; Dal Monte, M.; Martini, D.; Cammalleri, M.; Fortunato, P.; la Marca, G.; Fiorini, P.; Bagnoli, P. Role of the adrenergic system in a mouse model of oxygen-induced retinopathy: Antiangiogenic effects of $\beta$-adrenoreceptor blockade. Invest. Ophthalmol. Vis. Sci. 2011, 52, 155-170. [CrossRef]

171. Dal Monte, M.; Filippi, L.; Bagnoli, P. $\beta 3$-adrenergic receptors modulate vascular endothelial growth factor release in response to hypoxia through the nitric oxide pathway in mouse retinal explants. Naunyn Schmiedebergs Arch. Pharmacol. 2013, 386, 269-278. [CrossRef]

172. Steinle, J.J. Sympathetic neurotransmission modulates expression of inflammatory markers in the rat retina. Exp. Eye Res. 2007, 84, 118-125. [CrossRef]

173. Chisholm, K.M.; Chang, K.W.; Truong, M.T.; Kwok, S.; West, R.B.; Heerema-McKenney, A.E. Beta-adrenergic receptor expression in vascular tumors. Mod. Pathol. 2012, 25, 1446-1451. [CrossRef]

174. Lamkin, D.M.; Sloan, E.K.; Patel, A.J.; Chiang, B.S.; Pimentel, M.A.; Ma, J.C.; Arevalo, J.M.; Morizono, K.; Cole, S.W. Chronic stress enhances progression of acute lymphoblastic leukemia via beta-adrenergic signaling. Brain Behav. Immun. 2012, 26, 635-641. [CrossRef] [PubMed]

175. Perrone, M.G.; Notarnicola, M.; Caruso, M.G.; Tutino, V.; Scilimati, A. Upregulation of beta3-adrenergic receptor mrna in human colon cancer: A preliminary study. Oncology 2008, 75, 224-229. [CrossRef] [PubMed]

176. Calvani, M.; Pelon, F.; Comito, G.; Taddei, M.L.; Moretti, S.; Innocenti, S.; Nassini, R.; Gerlini, G.; Borgognoni, L.; Bambi, F.; et al. Norepinephrine promotes tumor microenvironment reactivity through $\beta 3$-adrenoreceptors during melanoma progression. Oncotarget 2015, 6, 4615-4632. [CrossRef]

177. Montoya, A.; Amaya, C.N.; Belmont, A.; Diab, N.; Trevino, R.; Villanueva, G.; Rains, S.; Sanchez, L.A.; Badri, N.; Otoukesh, S.; et al. Use of non-selective beta-blockers is associated with decreased tumor proliferative indices in early stage breast cancer. Oncotarget 2017, 8, 6446-6460. [CrossRef] [PubMed]

178. Daly, C.J.; McGrath, J.C. Previously unsuspected widespread cellular and tissue distribution of $\beta$-adrenoceptors and its relevance to drug action. Trends Pharmacol. Sci. 2011, 32, 219-226. [CrossRef] [PubMed]

179. Dal Monte, M.; Casini, G.; Filippi, L.; Nicchia, G.P.; Svelto, M.; Bagnoli, P. Functional involvement of $\beta 3$-adrenergic receptors in melanoma growth and vascularization. J. Mol. Med. 2013, 91, 1407-1419. [CrossRef] [PubMed]

180. Calvani, M.; Cavallini, L.; Tondo, A.; Spinelli, V.; Ricci, L.; Pasha, A.; Bruno, G.; Buonvicino, D.; Bigagli, E.; Vignoli, M.; et al. $\beta 3$-adrenoreceptors control mitochondrial dormancy in melanoma and embryonic stem cells. Oxid. Med. Cell Longev. 2018, 2018, 6816508. [CrossRef] [PubMed]

181. Calvani, M.; Bruno, G.; Dal Monte, M.; Nassini, R.; Fontani, F.; Casini, A.; Cavallini, L.; Becatti, M.; Bianchini, F.; De Logu, F.; et al. $\beta 3$-adrenoceptor as a potential immuno-suppressor agent in melanoma. Br. J. Pharmacol. 2019. [CrossRef]

182. Dal Monte, M.; Calvani, M.; Cammalleri, M.; Favre, C.; Filippi, L.; Bagnoli, P. Beta-adrenoceptors as drug targets in melanoma: Novel preclinical evidence for a role of $\beta 3$-adrenoceptors. Br. J. Pharmacol. 2018. [CrossRef]

183. Leineweber, K.; Buscher, R.; Bruck, H.; Brodde, O.E. Beta-adrenoceptor polymorphisms. Naunyn Schmiedebergs Arch. Pharmacol. 2004, 369, 1-22. [CrossRef]

184. Clement, K.; Vaisse, C.; Manning, B.S.; Basdevant, A.; Guy-Grand, B.; Ruiz, J.; Silver, K.D.; Shuldiner, A.R.; Froguel, P.; Strosberg, A.D. Genetic variation in the $\beta 3$-adrenergic receptor and an increased capacity to gain weight in patients with morbid obesity. N. Engl. J. Med. 1995, 333, 352-354. [CrossRef]

185. Walston, J.; Silver, K.; Bogardus, C.; Knowler, W.C.; Celi, F.S.; Austin, S.; Manning, B.; Strosberg, A.D.; Stern, M.P.; Raben, N.; et al. Time of onset of non-insulin-dependent diabetes mellitus and genetic variation in the $\beta 3$-adrenergic-receptor gene. N. Engl. J. Med. 1995, 333, 343-347. [CrossRef] 
186. Hoffstedt, J.; Poirier, O.; Thorne, A.; Lonnqvist, F.; Herrmann, S.M.; Cambien, F.; Arner, P. Polymorphism of the human $\beta 3$-adrenoceptor gene forms a well-conserved haplotype that is associated with moderate obesity and altered receptor function. Diabetes 1999, 48, 203-205. [CrossRef] [PubMed]

187. Ryuk, J.A.; Zhang, X.; Ko, B.S.; Daily, J.W.; Park, S. Association of $\beta 3$-adrenergic receptor rs4994 polymorphisms with the risk of type 2 diabetes: A systematic review and meta-analysis. Diabetes Res. Clin. Pract. 2017, 129, 86-96. [CrossRef] [PubMed]

188. Kurokawa, N.; Young, E.H.; Oka, Y.; Satoh, H.; Wareham, N.J.; Sandhu, M.S.; Loos, R.J. The ADRB3 Trp64Arg variant and BMI: a meta-analysis of 44833 individuals. Int J. Obes. 2008, 32, 1240-1249. [CrossRef]

189. Szendrei, B.; Gonzalez-Lamuno, D.; Amigo, T.; Wang, G.; Pitsiladis, Y.; Benito, P.J.; Gomez-Candela, C.; Calderon, F.J.; Cupeiro, R.; Group, P.S. Influence of ADRB2 Gln27Glu and ADRB3 Trp64Arg polymorphisms on body weight and body composition changes after a controlled weight-loss intervention. Appl. Physiol. Nutr. Metab. 2016, 41, 307-314. [CrossRef]

190. Daghestani, M.; Daghestani, M.; Daghistani, M.; Eldali, A.; Hassan, Z.K.; Elamin, M.H.; Warsy, A. ADRB3 polymorphism rs4994 (Trp64Arg) associates significantly with bodyweight elevation and dyslipidaemias in Saudis but not rs1801253 (Arg389Gly) polymorphism in ARDB1. Lipids Health Dis. 2018, 17, 58. [CrossRef]

191. Qu, H.C.; Zhang, W.; Liu, Y.L.; Wang, P. Association between polymorphism of $\beta 3$-adrenoceptor gene and overactive bladder: A meta-analysis. Genet. Mol. Res. 2015, 14, 2495-2501. [CrossRef]

192. Allison, D.B.; Heo, M.; Faith, M.S.; Pietrobelli, A. Meta-analysis of the association of the Trp64Arg polymorphism in the $\beta 3$ adrenergic receptor with body mass index. Int. J. Obes. Relat. Metab. Disord 1998, 22, 559-566. [CrossRef]

193. Rawson, E.S.; Nolan, A.; Silver, K.; Shuldiner, A.R.; Poehlman, E.T. No effect of the Trp64Arg $\beta 3$-adrenoceptor gene variant on weight loss, body composition, or energy expenditure in obese, caucasian postmenopausal women. Metabolism 2002, 51, 801-805. [CrossRef]

194. Teitsma, C.A.; de la Rosette, J.J.; Michel, M.C. Are polymorphisms of the $\beta 3$-adrenoceptor gene associated with an altered bladder function? Neurourol. Urodyn. 2013, 32, 276-280. [CrossRef]

195. Honda, K.; Nomiya, M.; Shishido, K.; Yoshimura, Y.; Yamaguchi, O. Mutation of $\beta 3$-adrenoceptor gene: A genetic marker for overactive bladder. In Neurourology and Urodynamics; John Wiley \& Sons: Hoboken, NJ, USA, 2006.

196. Fatima, T.; Altaf, S.; Phipps-Green, A.; Topless, R.; Flynn, T.J.; Stamp, L.K.; Dalbeth, N.; Merriman, T.R. Association analysis of the $\beta-3$ adrenergic receptor Trp64Arg (RS4994) polymorphism with urate and gout. Rheumatol. Int. 2016, 36, 255-261. [CrossRef] [PubMed]

197. Babol, K.; Przybylowska, K.; Lukaszek, M.; Pertynski, T.; Blasiak, J. An association between the Trp64Arg polymorphism in the $\beta 3$-adrenergic receptor gene and endometrial cancer and obesity. J. Exp. Clin. Cancer Res. 2004, 23, 669-674. [PubMed]

198. Huang, X.E.; Hamajima, N.; Saito, T.; Matsuo, K.; Mizutani, M.; Iwata, H.; Iwase, T.; Miura, S.; Mizuno, T.; Tokudome, S.; et al. Possible association of $\beta 2$ - and $\beta 3$-adrenergic receptor gene polymorphisms with susceptibility to breast cancer. Breast Cancer Res. 2001, 3, 264-269. [CrossRef] [PubMed]

199. Tan, W.; Gao, M.; Liu, N.; Zhang, G.; Xu, T.; Cui, W. Body mass index and risk of gallbladder cancer: Systematic review and meta-analysis of observational studies. Nutrients 2015, 7, 8321-8334. [CrossRef] [PubMed]

200. Bardou, M.; Loustalot, C.; Cortijo, J.; Simon, B.; Naline, E.; Dumas, M.; Esteve, S.; Croci, T.; Chalon, P.; Frydman, R.; et al. Functional, biochemical and molecular biological evidence for a possible $\beta 3$-adrenoceptor in human near-term myometrium. Br. J. Pharmacol. 2000, 130, 1960-1966. [CrossRef] [PubMed]

201. Rouget, C.; Bardou, M.; Breuiller-Fouche, M.; Loustalot, C.; Qi, H.; Naline, E.; Croci, T.; Cabrol, D.; Advenier, C.; Leroy, M.J. $\beta 3$-adrenoceptor is the predominant beta-adrenoceptor subtype in human myometrium and its expression is up-regulated in pregnancy. J. Clin. Endocrinol. Metab. 2005, 90, 1644-1650. [CrossRef]

202. Hadi, T.; Douhard, R.; Dias, A.M.M.; Wendremaire, M.; Pezze, M.; Bardou, M.; Sagot, P.; Garrido, C.; Lirussi, F. $\beta 3$ adrenergic receptor stimulation in human macrophages inhibits nadphoxidase activity and induces catalase expression via ppargamma activation. Biochim. Biophys. Acta Mol. Cell Res. 2017, 1864, 1769-1784. [CrossRef] [PubMed]

(C) 2019 by the authors. Licensee MDPI, Basel, Switzerland. This article is an open access article distributed under the terms and conditions of the Creative Commons Attribution (CC BY) license (http://creativecommons.org/licenses/by/4.0/). 